\title{
PALYNOSTRATIGRAPHY OF THE CRETACEOUS-PALEOGENE IN THE AUSTRAL BASIN, SW SANTA CRUZ PROVINCE, ARGENTINA
}

\author{
LETICIA POVILAUSKAS \\ División Paleobotánica, Museo de La Plata, UNLP, Paseo del Bosque s/n, C1900DJR, \\ La Plata, Buenos Aires, Argentina. lepovilauskas@gmail.com
}

\begin{abstract}
This paper analyses the palynological assemblages recovered from the Cerro Cazador and Monte Chico formations and is an exhaustive study of the spore-pollen assemblages from the Cerro Dorotea Formation; all units with outcrops out in southwestern Santa Cruz Province, Argentina. Six sections were sampled in two main areas: Estancia San José and Estancia Laguna Salada. The palynological assemblages yielded by the studied formations are integrated with elements of marine (dinoflagellate cysts and acritarchs) and continental (spores and pollen grains) origin, present in different proportions throughout these units. Forty one species of pollen grains and spores were recognized in the Cerro Cazador Formation, 74 genera and 127 species in the Monte Chico Formation and 64 genera and 107 species in the Cerro Dorotea Formation. On the basis of the stratigraphic distribution of the identified species, four palynological assemblages were recognized, which were defined by the exclusive presence of characteristic species and their similarities with other spore-pollen assemblages. The following ages were suggested: (i) Association 1, upper sections of the Cerro Cazador Formation: upper Campanian-lower Maastrichtian; (ii) Association 2, lower and middle levels of the Monte Chico Formation: Maastrichtian, probably upper Maastrichtian; (iii) Association 3, upper levels of the Monte Chico Formation: Maastrichtian-Danian; and (iv) Association 4, Cerro Dorotea Formation: Danian. Based on this analysis, the K/P boundary is located between Associations 2 and 3, within the Monte Chico Formation. These palynological assemblages indicate a near-shore marine depositional environment close to the coastline, with marginal conditions, and a progressive shallowing of the basin.
\end{abstract}

Key words: palynostratigraphy, pollen grains, spores, Cretaceous, Paleogene, Santa Cruz Province.

RESUMO - Nesta contribuição são apresentadas as associações palinológicas das formações Cerro Cazador e Monte Chico, associações esporopolínicas da Formação Cerro Dorotea, no sudoeste da Província de Santa Cruz, Argentina. Seis seções foram amostradas em duas áreas principais: Estancia San José e Estancia Laguna Salada. As associações palinológicas são constituídas por elementos de origem marinha (cistos de dinoflagelados e acritarcas) e continental (grãos de pólen e esporos), presentes em diferentes proporções ao longo destas unidades. Quarenta e uma espécies de grãos de pólen e de esporos foram identificadas na Formação Cerro Cazador, 74 gêneros e 127 espécies na Formação Monte Chico e 64 gêneros e 107 espécies na Formação Cerro Dorotea. Com base na distribuição estratigráfica das espécies identificadas, e semelhanças com outras associações esporopolínicas, foram reconhecidas quatro associações palinológicas, com as seguintes idades: (i) Associação 1, secção superior da Formação Cerro Cazador: Campaniano superior-Maastrichtiano inferior; (ii) Associação 2, níveis mais baixos e médios da Formação Monte Chico: Maastrichtiano, provavelmente Maastrichtiano superior; (iii) Associação 3, níveis superiores do Formação Monte Chico: Maastrichtiano-Daniano e (iv) Associação 4, Formação Cerro Dorotea: Daniano. Com base nesta análise, o limite K/P localiza-se entre Associações 2 e 3, dentro da Formação Monte Chico. Estas associações palinológicas sugerem paleoambiente de deposição marinho proximal, em condições marginais e continentalização progressiva da bacia.

Palavras-chaves: palinoestratigrafía, grãos de pólen, esporos, Cretáceo, Paleógeno, Província de Santa Cruz.

\section{INTRODUCTION}

In this contribution the spore-pollen associations of the Cerro Cazador, Monte Chico and Cerro Dorotea formations cropping out in the Estancia San Jose and Estancia Laguna Salada areas are studied. The study area is located at the most southwestern extreme of the Province of Santa Cruz (Figure 1). Palynological sampling was conducted in several sections exposed in outcrops near the area of Cancha Carrera $\left(51^{\circ} 11^{\prime} 20.2^{\prime \prime} \mathrm{S}, 72^{\circ} 20^{\prime} 55.5^{\prime \prime} \mathrm{W}\right)$, and in the area of Cerro de la Cruz, near Rio Turbio City (51'33'00.5”S, $\left.72^{\circ} 25^{\prime} 43.2^{\prime \prime} \mathrm{W}\right)$, forming an integrated profile of the entire analyzed sequence (Figures 2, 3).

\section{GEOLOGICAL FRAMEWORK}

The Cerro Cazador Formation consists of fine to mediumgrained sandstones with interbedded calcarenites, in part glauconitic, with claystones, conglomerates and limestone banks with pelecypod remains and gastropods (Riccardi \& Rolleri, 1980).

This formation is restricted to the sequence of "green sandstones" of Hauthal (1898), the Lahillia luisa Layers of Wilckens (1907), the lower levels of the "middle section of the Green Sandstone" of Brandmayr (1945), the sediments that Feruglio $(1938,1949)$ recognized as the "strata of Monte Cazador" or "Lahillia luisa Layers", the basal section and 


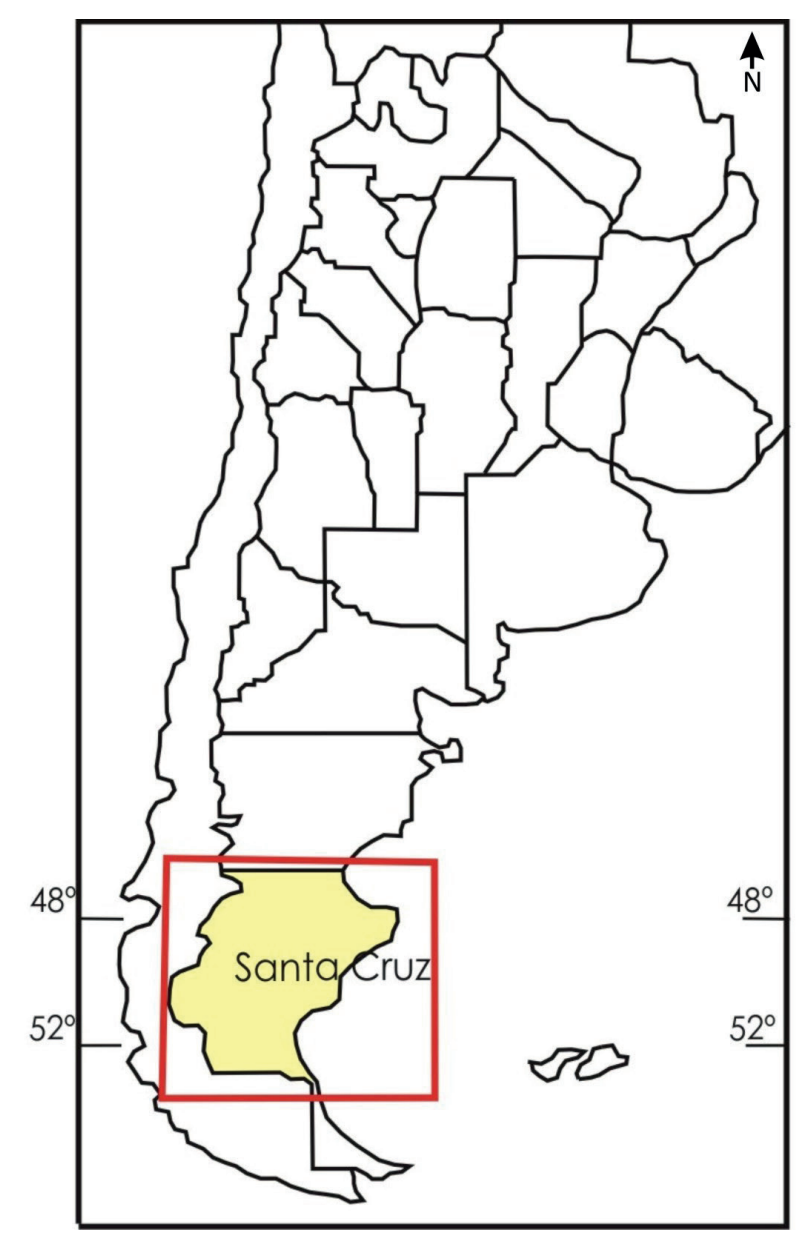

Figure 1. Location map of the study area.

the lower part of the middle of the "Cerro Cazador Strata or Lahillia luisa Layers" of Hünicken (1955), the Cerro Cazador Group of Borrello (1956), the Dorotea Formation of Katz (1963) and the Cerro Cazador Formation of Leanza (1972) (Table 1).

This unit conformably overlies the Cerro Toro Formation and is unconformably overlain by the Monte Chico Formation, so is assigned to the Campanian-Maastrichtian on the basis of its stratigraphic relationships (Malumián \& Panza, 1996).

The Monte Chico Formation is composed of fine to mediumgrained sandstone, brown, light brown to reddish and greenish gray, partly calcareous, with abundant dark gray concretions including invertebrate megafauna fossils, mudstone, limonite and conglomerates interbedded with coquinoid megafossil beds (Malumián \& Panza, 1996) (Figure 3). The Monte Chico Formation corresponds to the upper levels of the "Middle Section of the Green Sandstone" of Brandmayr (1945), the strata of the Cerro Cazador or Lahillia luisa Layers of Feruglio $(1938,1949)$ and Hünicken (1955), the Cerro Cazador Formation of Leanza (1972) and the lower levels of the Dorotea Formation of Katz (1963). This paper follows the stratigraphic outline presented by Malumián \& Panza (1996), who gave the formal description of the Monte Chico Formation, supporting the discordant relationship of the base of this unit, which shows a transgressive base overlying

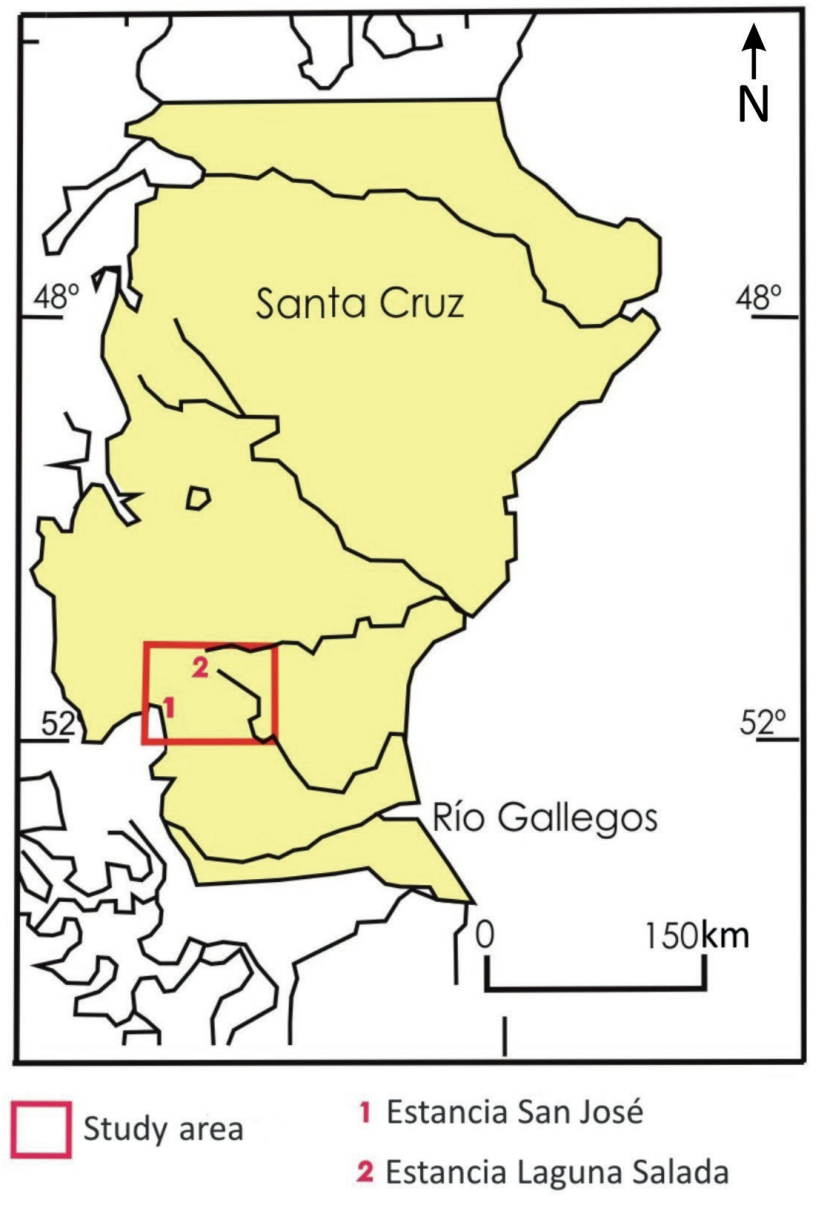

sedimentary units of different areas. The upper boundary is concordant and gradual with the Cerro Dorotea Formation. The Monte Chico Formation correlates with the Calafate Formation; both are of Cretaceous age, the same lithology and show similar stratigraphic relationships.

The Cerro Dorotea Formation corresponds to the "strata of the Cerro Dorotea" of Feruglio $(1938,1949)$, and the "upper section of the Green Sandstone" or strata with Ostrea rionegrensis of Brandmayr (1945). The Dorotea Formation of Cecioni (in Hoffstetter et al., 1957) or the Sierra Dorotea Group of Borrello (1956) do not include the same sequence as the Cerro Dorotea Formation as defined here, because the former included the strata of Monte Grande, the Cerro Cazador Layers and the Cerro Dorotea Layers since Cecioni considered it impossible to distinguish between these strata lithologically. Borrello (1956) divided the Sierra Dorotea Group into three sections: lower, middle and upper. The lower section corresponds to the Cerro Dorotea Formation (Figure 2). Some pelitic levels and coal strata have a gradual transitional relationship over the strata of the Monte Chico Formation (Malumián \& Panza, 1996). To the SE of Estancia Laguna Salada and after about 500 meters of vegetationcovered rocks, there are outcrops of the top of the Cerro Dorotea Formation, consisting of shales, sandstones and conglomerate packages. 

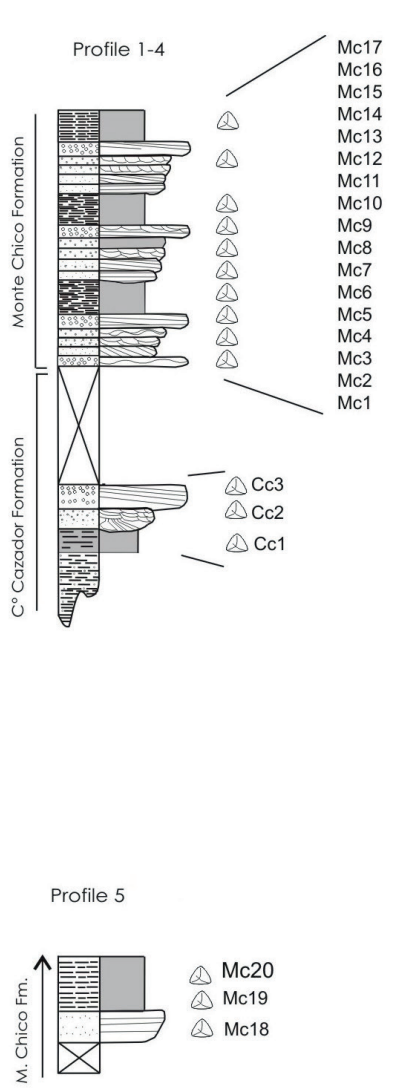
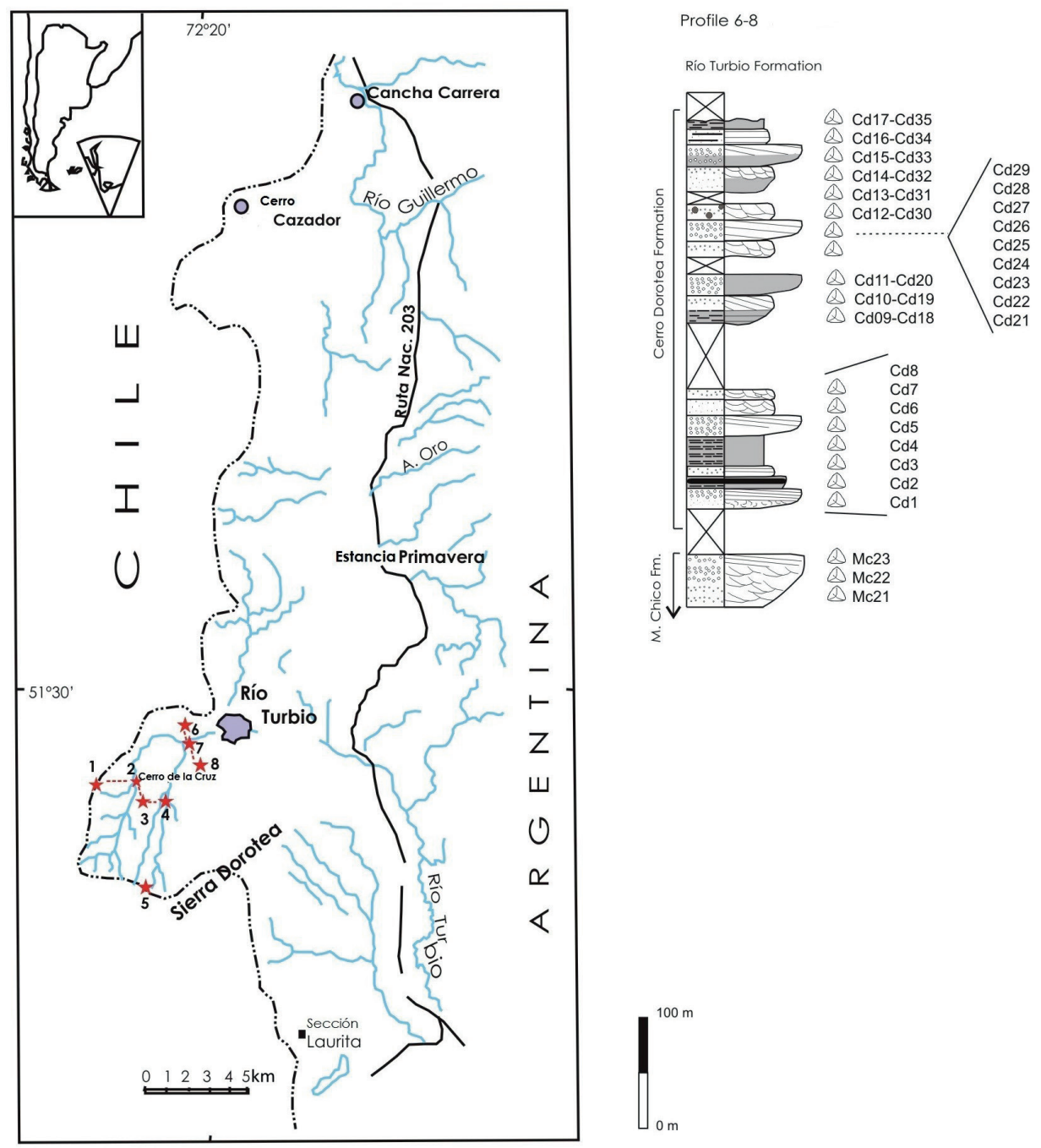

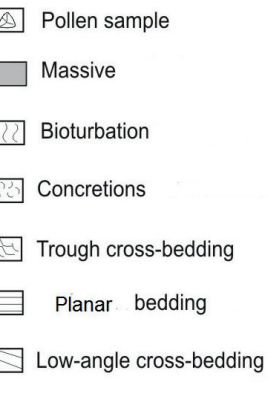

Flaser or lenticular bedding

Figure 2. Stratigraphic section in Cerro de la Cruz area, near the city of Rio Turbio, Santa Cruz Province, Argentina.

The objective of this paper is to present the palynoflora from the Cerro Cazador, Monte Chico and Cerro Dorotea formations, with the aim of identifying one or several areas with restricted distributions of taxa, capable of being useful as a guide, to infer the relative age and to define the depositional paleoenvironment. All profiles were made in a west-east direction, perpendicular to the strike of the strata that has an inclination of $5^{\circ}$ to $25^{\circ}$ east. The exposed banks are conglomerate-bearing silicified masses, representing a period of greater energy input, with related sections of pelitic and coarsening-upward sandstone sequences. It represents a marine depositional environment with little internal communication between the platform and the open sea (Malumián \& Panza, 1996). A preliminary palynological analysis of Cretaceous sequences near the study area (Povilauskas et al., 2006; Povilauskas \& Guler, 2008) suggested a coastal marine depositional environment close to the coastline, and an age of Maastrichtian-late Maastrichtian. 

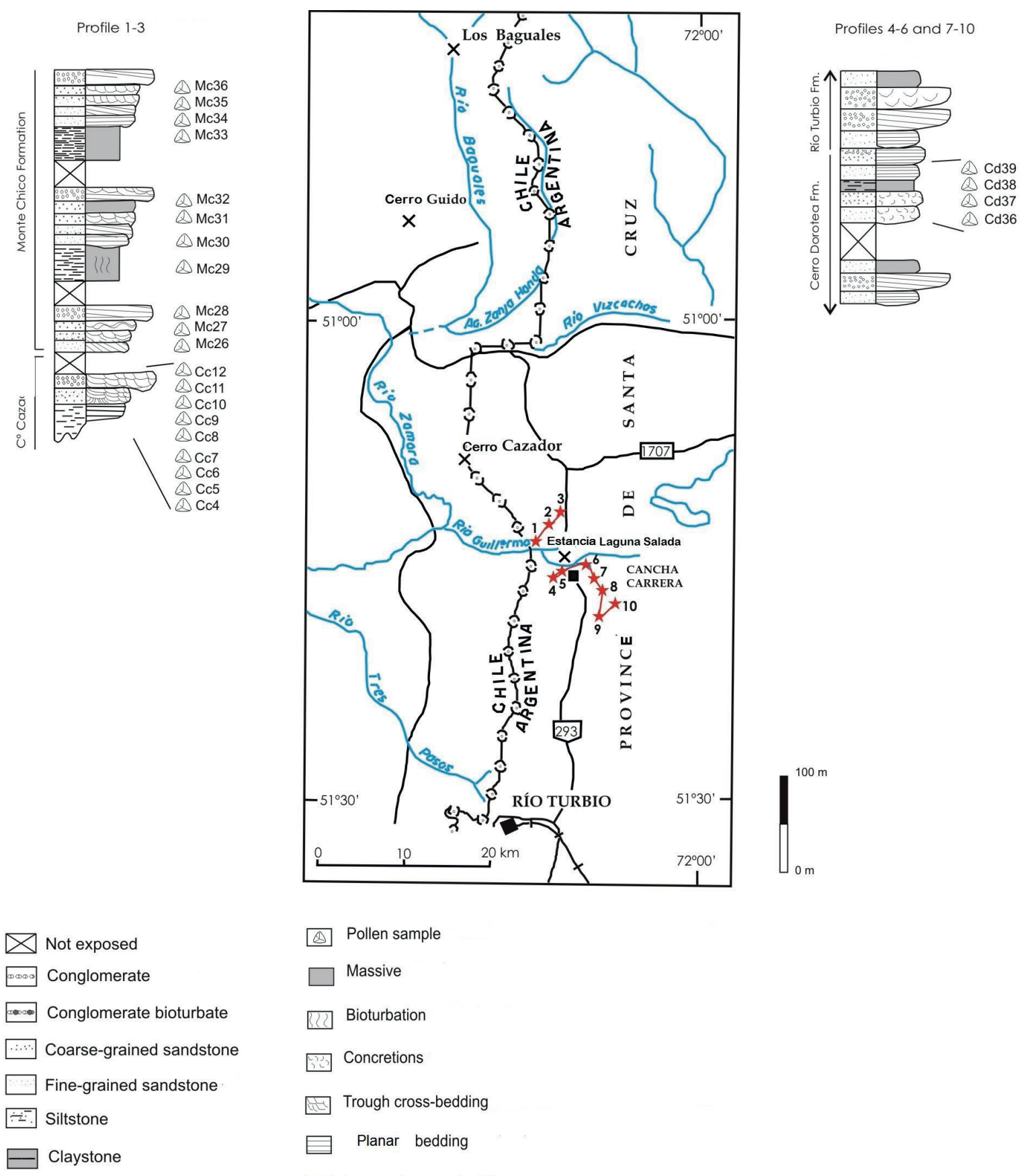

Low-angle cross-bedding

Flaser or lenticular bedding

Figure 3. Stratigraphic section in Estancia Laguna Salada area, near of Cancha Carrera, Santa Cruz Province, Argentina.

\section{MATERIAL AND METHODS}

For the collection of the samples the best areas of exposure were chosen between the two areas of study (Estancia San José and Estancia Laguna Salada) (Figures 2, 3). A difficulty with sampling was that in several sections of interest a considerable percentage of the profiles were covered by vegetation, leaving only relatively small stratigraphic intervals for extraction of samples. The distance between samples was irregular, depending on the lithology and the sections covered. At appropriate intervals sampling was conducted at a distance of $5 \mathrm{~m}$. The collected material was bagged for subsequent laboratory analysis.

Palynological extraction was performed according to the conventional methods of physical and chemical extraction (HCl-HF) (Volkheimer \& Melendi, 1976) and the residue 
obtained was filtered through mesh $(+10$ and +25 microns $)$. The final preparations were mounted in glycerine gelatin. The specimens were studied with a Leitz Wetzlar microscope and Olympus BX51 microscope (Germany/Japan) in the Paleopalynology Section and photographs were taken with a transparent optical microscope and scanning electron microscope (SEM) at the Argentinian Museum of Natural Sciences "Bernardino Rivadavia". For photo documentation of the specimens a Nikon E4500 digital camera was used. Classification is considered semi-natural and identifies taxa to genus and species. The terminology used follows Punt et al. (2007).

The preparations are reposited in the Regional Provincial Museum "Padre Manuel Jesús Molina" in Rio Gallegos, Santa Cruz Province, Argentina, under the prefix MPM-MP with catalog numbers 1943 to 1978.

\section{PALYNOSTRATIGRAPHY}

On the basis of this analysis four spore-pollen associations characterized by groups of species with restricted distributions were recognized. Figure 4 shows the distribution of the species identified in the formations studied. In the associations groups of species common to the three formations were also identified, which, if they are not useful for the purposes of a biozone characterization, are useful for characterizing the whole association.

Among them Arecipites minutiscabratus, Baculatisporites comaumensis, Clavifera triplex, Cyatheacidites annulatus, Gleicheniidites senonicus, Liliacidites kaitangataensis, Nothofagidites saraensis and Polypodiidites speciosus are the most significant.

The four spore-pollen associations have characteristics that allow them to be clearly distinguished from each other. The transitions between these associations appear to be gradual. The changes were observed in both taxonomic composition and in the relative abundance of the palynomorphs.

Assemblage 1. Is characterized by the exclusive presence of Baculatisporites cf. B. comaumensis, Biretisporites cf. B. potoniaei, Ischyosporites sp. 1, Trilites cf. T. fasolae, Verrucosisporites sp. 2, Podocarpidites sp. 2 and Triporopollenites sp. 1, with the absence of the distinctive features of higher associations (from the Monte Chico and Cerro Dorotea formations). This association comes from the upper levels of the Cerro Cazador Formation (see appendix 1). Assemblage 2. Is characterized by the exclusive presence of Beaupreaidites elegansiformis, Camarozonosporites ohaiensis, Ceratosporites equalis, Forcipites sabulosus, Haloragacidites trioratus, Ilexpollenites salamanquensis, Liliacidites vermireticulatus, Longapertites patagonicus, Ornamentifera echinata, Proteacidites subscabratus, Quadraplanus brossus, Rhoipites baculatus, Rousea microreticulata, Senipites tercrassata, Tricolpites bibaculatus and Tuberculatosporites parvus and the absence of characteristic elements of the lower (1) and upper $(3,4)$ associations. Also in this association are the first records of Baculatisporites turbioensis, Biretisporites crassilabratus,
Classopollis sp. 1, Nothofagidites kaitangataensis, Peninsulapollis truswellidae, Periporopollenites demarcates, Peromonolites vellosus, Proteacidites beddoesii, Proteacidites tenuiexinus, Psilatricolpites patagonicus, Psilatricolporites $\mathrm{cf}$. P. salamanquensis, Rhoipites minusculus, Rousea patagonica, Sparganiaceapollenites barungensis, Spinizonocolpites hialinus, Triatriopollenites bertelsii, Trilites tuberculiformis and Triporopollenites cf. T. ambiguus. This association comes from the basal levels and middle of the Monte Chico Formation (see appendix 1).

Assemblage 3. Is characterized by the exclusive presence of Beaupreaidites sp. 1, Liliacidites sp. 1, Peninsulapollis askiniae and Pseudowinterapollis couperi and the absence of distinctive elements of associations 1,2 and 4. This association comes from the upper levels of the Monte Chico Formation. In this association are the first records of Ericipites scabratus, Gamerroites psilasaccus, Nothofagidites dorotensis and Nothofagidites nana (see appendix 1).

Assemblage 4. Is characterized by the exclusive presence of Bombacacidites sp. 1, Forcipites stipulatus, Nothofagidites waipawaensis, Propylipollis microverrucatus and Tetracolporites sp. 1, and the absence of the distinctive elements of the lower associations (1, 2 and 3). This association comes from the Cerro Dorotea Formation (see Appendix 1).

\section{AGE OF ASSOCIATIONS}

The age of the associations identified is inferred on the basis of: (i) known temporal ranges of the species present in each of the associations, and (ii) the similarities to other previously studied palynological associations, especially those from Campanian, Maastrichtian and Paleocene sequences of Argentina and Antarctica (Table 2). The associations that were used for comparison in this analysis were the Pedro Luro Formation, Maastrichtian-Danian, Buenos Aires Province (Ruiz \& Quattrocchio, 1997); the Loncoche Formation, Maastrichtian, Mendoza Province (Papú, 2002); the Los Alamitos Formation, upper Campanian, Río Negro Province (Papú \& Sepúlveda, 1995); the Paso del Sapo Formation, Maastrichtian, Chubut Province (Papú, 1988a,b, 1989); the Lefipán Formation, Maastrichtian, Chubut Province (Baldoni, 1992; Baldoni \& Askin, 1993); the Salamanca Formation, Danian, Chubut Province (Archangelsky, 1973; Archangelsky \& Zamaloa, 1986); the Lopez de Bertodano Formation, Maastrichtian-Danian, Antarctic Peninsula (Baldoni \& Barreda, 1986; Askin, 1988, 1990) and the La Irene Formation, Maastrichtian-Danian, Santa Cruz Province (Povilauskas et al., 2008).

\section{Assemblage 1}

Species exclusive to this association have greater stratigraphic significance as they have been identified in other basins in Argentina within a bounded time range. Only the records of Nothofagidites saraensis and Peninsulapollis gillii, also present in higher associations (from the Monte Chico Formation), constrain the maximum age limit of the 


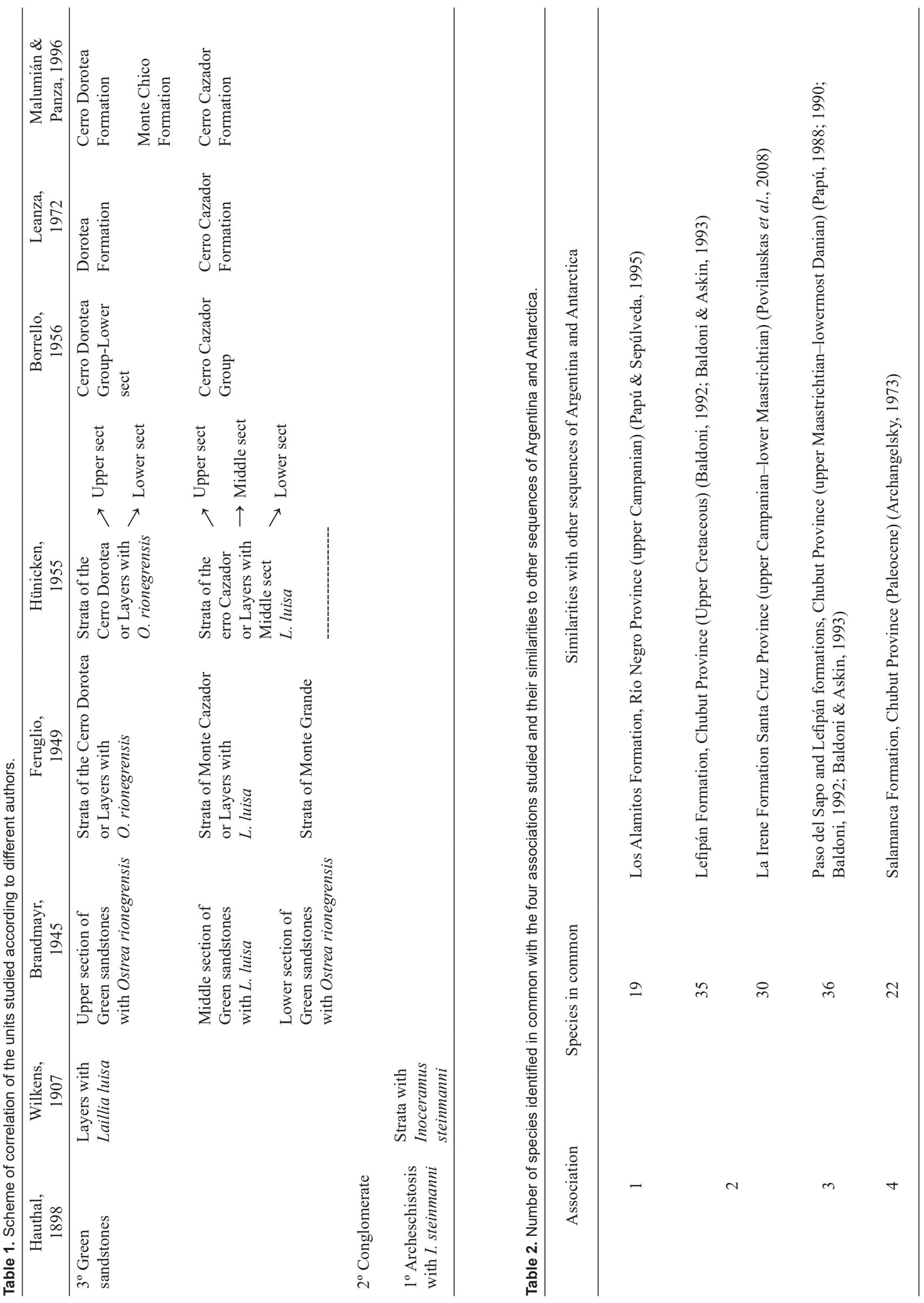


Figure 4. Stratigraphic distribution of selected species and recognized in the Cerro Cazador, Monte Chico and Cerro Dorotea formations.

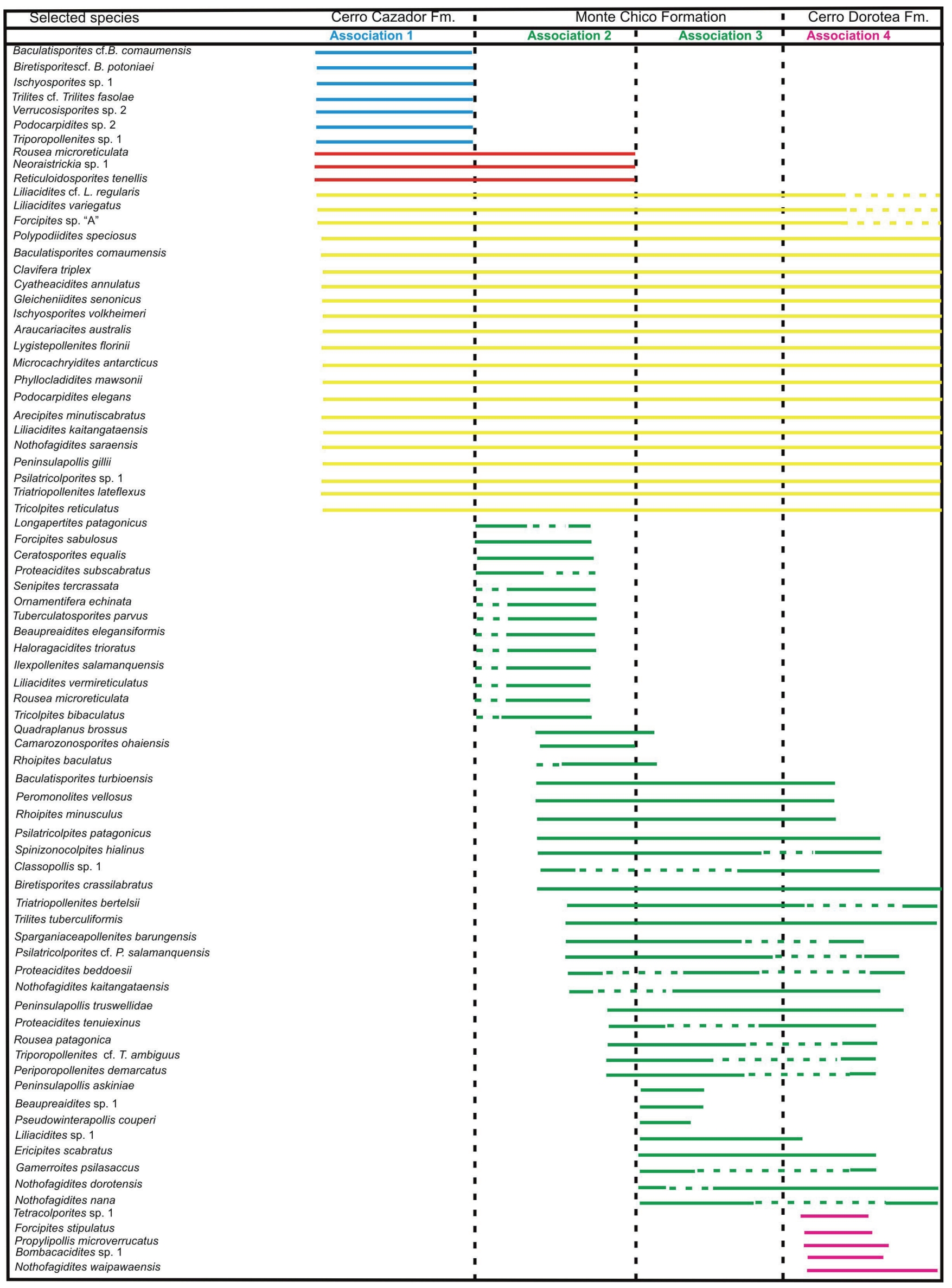


association. These two species do not have records prior to the late Campanian in Patagonia and Antarctica or Australia (Baldoni \& Barreda, 1986; Askin, 1988, 1990; Papú, 1990; Baldoni \& Askin, 1993; Dettmann \& Thompson, 1987; Dettmann \& Jarzen, 1988).

The greatest similarities of Association 1 (Cerro Cazador Formation) occur with an association from the Los Alamitos Formation, upper Campanian, Río Negro Province (Papú \& Sepúlveda, 1995), which shares many of the species present, such as Araucariacites australis, Clavifera triplex, Cyatheacidites annulatus, Cyathidites minor, Gleicheniidites senonicus, Liliacidites spp., Microcachryidites antarcticus, Neoraistrickia sp., Peninsulapollis gillii, Podocarpidites spp., Stereisporites antiquasporites, Tricolpites reticulatus and freshwater algae such as Botryococcus sp., among others (Table 3). Other recovered associations from Patagonia, from the Loncoche Formation, Maastrichtian of Mendoza Province (Papú, 2002), also have significant numbers of common species: 14 species. Antarctic associations, however, dominated by Nothofagaceae and Podocarpaceae (Baldoni \& Barreda, 1986; Dettmann \& Thomson, 1987; Askin, 1990), have low overall similarities. In the Cerro Cazador Formation Nothofagaceae (Nothofagidites saraensis) are recognized but in very low proportions.

Also dinoflagellate cysts present in the lower levels of the studied section (CC4, CC5, CC6 and CC7), represented by the family Peridiniaceae including Cerodinium sp. Diconodinium sp, Isabelidiniium sp. cf. I. pellucidum, Nelsoniella sp., Odontochitina spinosa, Odontochitina spp., Palaeocystodinium australinum, P. granulatum, P. lidiae, Spinidinium sp., with lower proportions of the Family Goniaulacoideae such as Exochosphaeridinum sp. and Spiniferites ramosus (Povilauskas \& Guler, 2008), suggest an age of late Campanian-early Maastrichtian. This age would be consistent with that suggested by the spore-pollen associations.

\section{Assemblage 2}

In this group, some of the exclusive Association 2 taxa (lower levels of the Monte Chico Formation) are important from a chronostratigraphic standpoint. Among the most significant species are Longapertites patagonicus, in Argentina related to Danian deposits of Chubut Province (Archangelsky, 1973) and the oldest records in the Maastrichtian of the same province (Baldoni, 1992; Baldoni \& Askin, 1993); Proteacidites subscabratus, defined in New Zealand for the Oligocene, and recognized in Argentina and the Antarctic in the Maastrichtian-Danian; Senipites tercrassata, defined for the Paleocene of Argentina (Archangelsky, 1973); Beaupreaidites elegansiformis, also distributed in the Campanian-Maastrichtian of Australia, the Antarctic and New Zealand (Dettmann \& Jarzen, 1988; 1990; Cookson, 1950); Ilexpollenites salamanquensis, recognized from the Upper Cretaceous of New Zealand (Mc Intyre, 1968) and recorded from the Paleocene of Argentina (Archangelsky \& Zamaloa, 1986); Liliacidites vermireticulatus, defined in Argentina and distributed from the lower Paleocene
(Archangelsky \& Zamaloa, 1986; Mautino \& Anzótegui, 2002); Tricolpites bibaculatus, defined and distributed in the Paleocene of Argentina (Archangelsky \& Zamaloa, 1986; Quattrocchio et al., 1997); and Quadraplanus brossus, recognized primarily in Australia with a very restricted acme to the upper Maastrichtian-basal Danian? (Stover \& Partridge, 1973; Helby et al., 1987).

Neverthless, other stratigraphic taxa listed in Association 2 are also important and continue to be recorded towards the top of the Monte Chico Formation (Association 3). Among them, the most significant are Psilatricolporites cf. P. salamanquensis, Rhoipites minusculus, Rousea patagonica, Spinizonocolpites hialinus and Triporopollenites cf. T. ambiguus, all features of Maastrichtian and Danian associations of Argentina (Archangelsky, 1973; Archangelsky \& Zamaloa, 1986; Baldoni, 1992; Baldoni \& Askin, 1993).

Association 2 presents the greatest similarities with associations from the Lefipán Formation, Upper Cretaceous of Chubut Province (Baldoni, 1992; Baldoni \& Askin, 1993) and the La Irene Formation, upper Campanian-lower Maastrichtian of Santa Cruz Province (Povilauskas et al., 2008), with whom it shares species such as Liliacidites variegatus, Liliacidites kaitangataensis, Longapertites patagonicus, Spinizonocolpites hialinus, Tricolpites reticulatus, Peninsulapollis gillii, Rousea patagonica, Rhoipites minusculus, Triporopollenites ambiguus, Proteacidites tenuiexinus and Triatriopollenites lateflexus, among others (Table 4).

Given the similarities to known biochrons, an age related to the Maastrichtian, probably late Maastrichtian, for the Association 2 (lower levels of the Monte Chico Formation) is suggested (Figure 5).

\section{Assemblage 3}

Among the taxa represented exclusively in this association that have stratigraphic significance is Peninsulapollis askiniae; this species was defined for the Upper Cretaceous of Australia and Antarctica (Dettmann \& Jarzen, 1988; Dettmann \& Thomson, 1987; Truswell, 1983), but in Argentina is recognized from the Paleocene (Archangelsky \& Seoane, 1994).

The greatest similarities of Association 3 occur with those from the Paso del Sapo and Lefipán formations (Papú, 1988a, 1988b, 1990; Baldoni, 1992; Baldoni \& Askin, 1993), assigned to the upper Maastrichtian-basal Danian.

Based on this analysis, Association 3 is referred to the higher levels of the Monte Chico Formation around Maastrichtian-Danian in age. The increased diversity of Nothofagidites spp., together with the first records of Nothofagidites dorotensis and the extinction of Quadraplanus brossus might suggest a greater time restriction (basal Danian?) (Table 4). Nothofagidites dorotensis was defined in Argentina and recorded only from the Paleocene (Romero, 1973; Menéndez \& Caccavari, 1975); meanwhile Quadraplanus brossus is an important guide fossil not documented beyond the base of the Danian. 


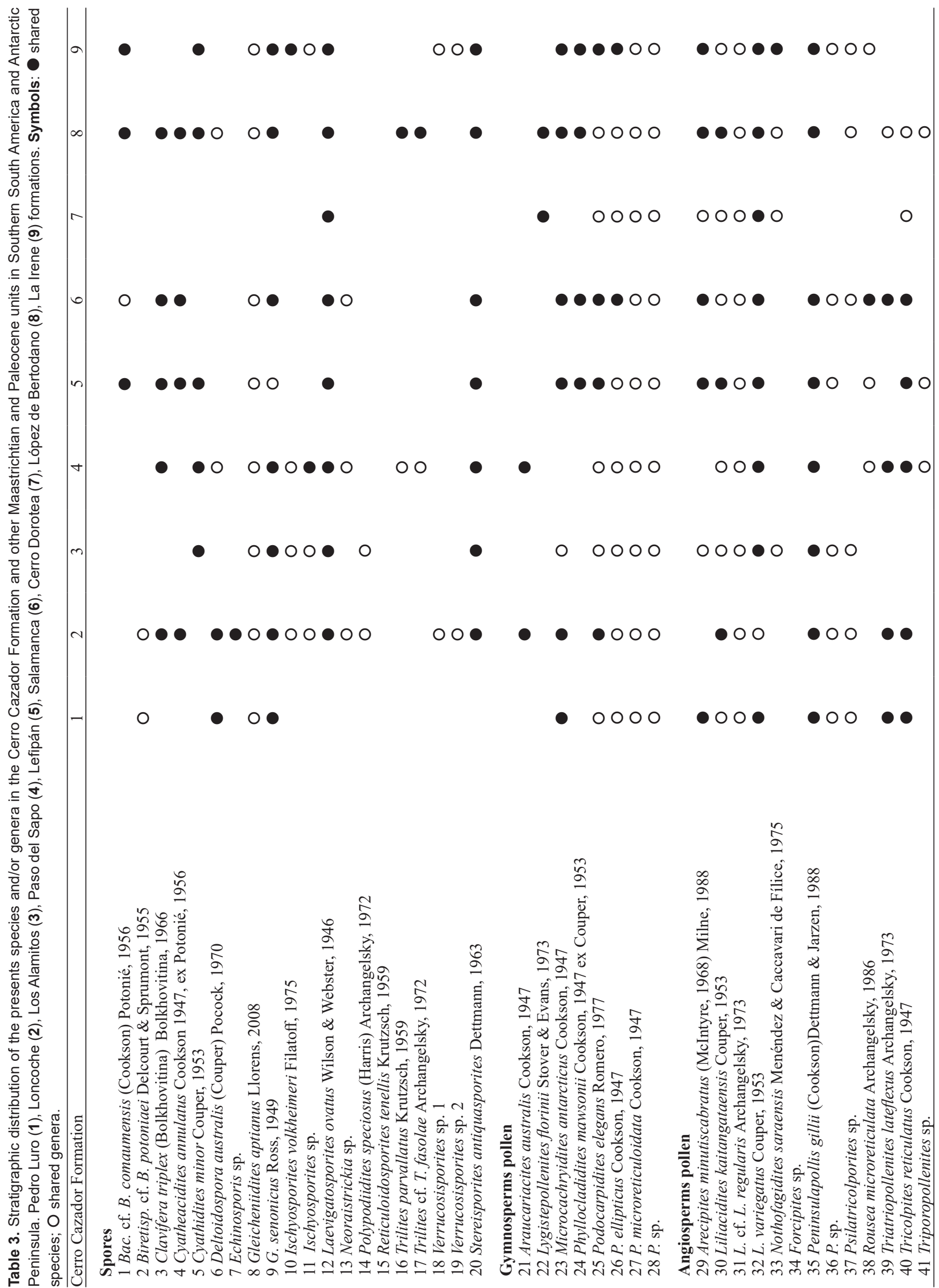




\section{Assemblage 4}

Association 4 (Cerro Dorotea Formation) is characterized by the exclusive presence of, among other species, Bombacacidites sp. 1, Forcipites stipulatus, Nothofagidites waipawaensis and Propylipollis microverrucatus (Table 5).

From a chronostratigraphic point of view, among the most significant is Forcipites stipulates, defined in Australia and recognized from the Maastrichtian in Australia and Antarctica (Dettmann \& Jarzen, 1988), without previous records in Argentina, and Nothofagidites waipawaensis, defined in Argentina, and recognized from the lower Paleocene (Romero, 1973; Romero \& Zamaloa, 1997; Carrillo-Berumen et al., 2013).

For its part, the greatest similarities of Association 4 (Cerro Dorotea Formation) occur with those from the Salamanca Formation (Paleocene) (Archangelsky, 1973). They share the presence of Clavifera triplex, Cyatheacidites annulatus, Arecipites minutiscabratus, Liliacidites variegatus, Nothofagidites spp., Rhoipites minusculus, Rousea patagonica, Spinizonocolpites hialinus, Triatriopollenites lateflexus, Tricolpites reticulatus, Liliacidites regularis, Psilatricolporites salamanquensis and Ericipites scabratus among the most significant taxa.

In comparison to the known biochrons spanning the stratigraphic position of the Cerro Dorotea Formation, some of the species found, and with special regard to the similarities found with other formations, suggest a similar age in the Danian. This temporal assignment is consistent with that previously indicated by Freile (1972) based on a preliminary palynological study of the Cerro Dorotea Formation.

\section{PALEOECOLOGICAL IMPLICATIONS}

Fossil evidence indicates that different groups experienced a global extinction event across the Cretaceous/Paleogene boundary. It eliminated $80 \%$ of marine invertebrates, the extinction of the dinosaurs occurred and there was a drastic reduction of many species of mammals (Pascual et al., 1985; Pascual \& Jaureguizar, 1990). The evidence of a comparable extinction to that of the fauna in the flora is ambiguous at least in the Southern Hemisphere (Diéguez, 2003). In the Northern Hemisphere in various sections of North America, and also in Japan and Europe there was a violent and rapid decline in the abundance and diversity of various plant groups across the area (Orth et al., 1981). This process was followed by a significant increase in the concentration of spores of ferns, an event known as the "fern spike". The latter was interpreted as a response of vegetation to strong ecological trauma. The vegetation diversity is later restored, but with a different composition to that presented before the $\mathrm{K} / \mathrm{T}$ boundary. In the Southern Hemisphere the marine biota was as affected as in the Northern Hemisphere, but until recently there was no evidence of substantial changes in plant communities across the area. Palynological studies conducted in Australia and Antarctica showed very little change through the CretaceousPaleogene (Askin, 1988; Macphail, 1994). However, recent studies in New Zealand and Argentina showed a disturbance

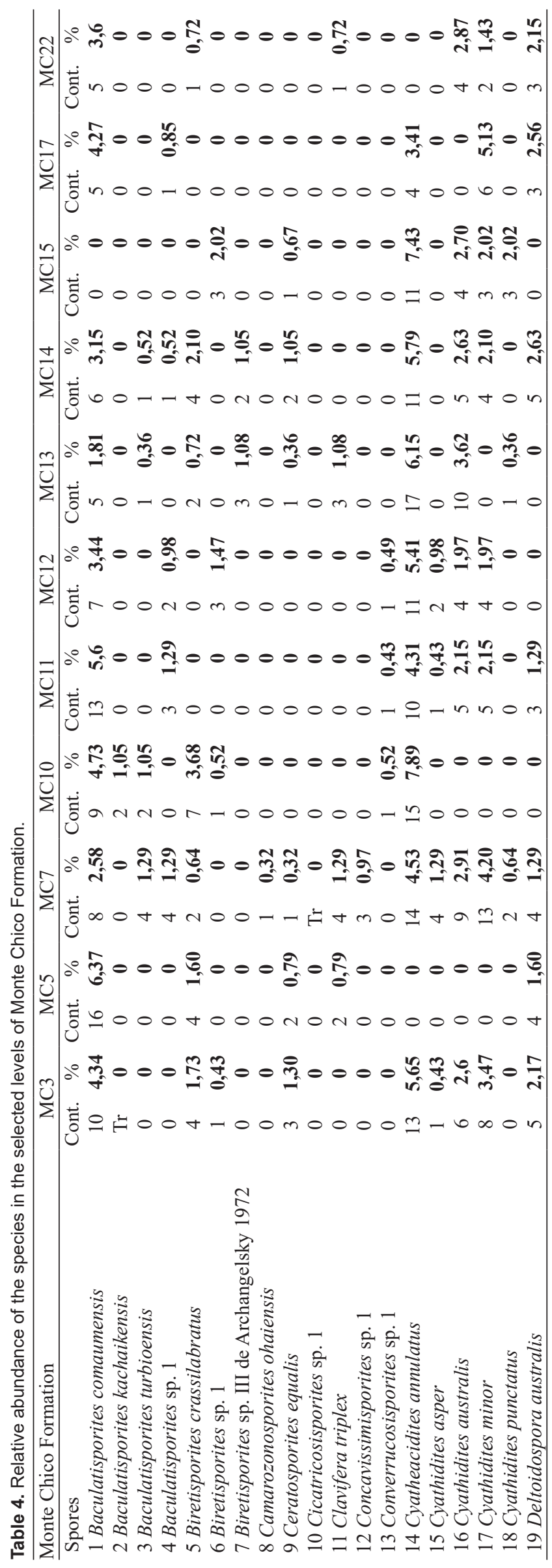




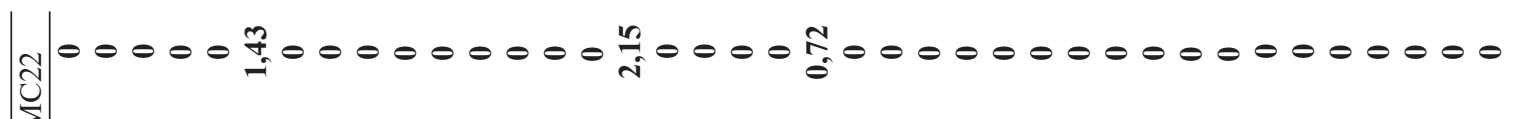

$\sum 00000 \mathrm{~N} 000000000 \mathrm{~m} 0000-000000000000000000$

อิ

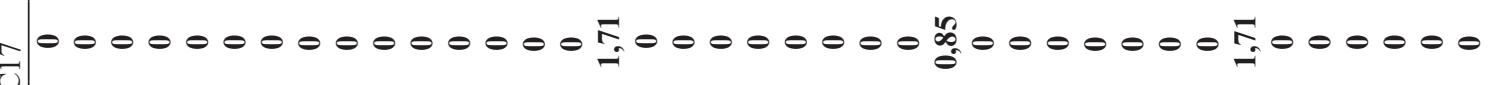

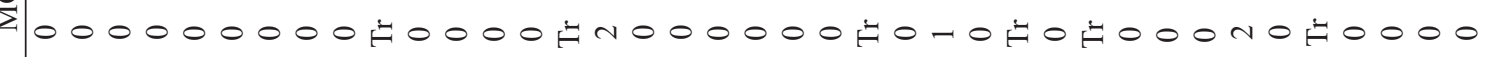

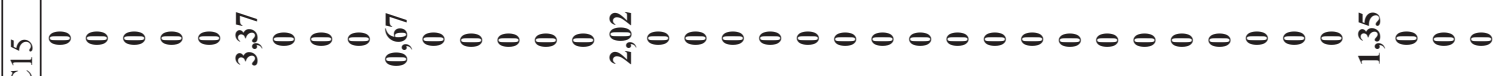

$\sum$

$\Sigma 00000$ n

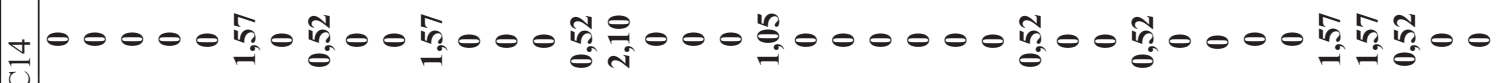

$\Sigma 00000 m 0-00 m 000-t 000 N 000000-00-0000 m m-00$

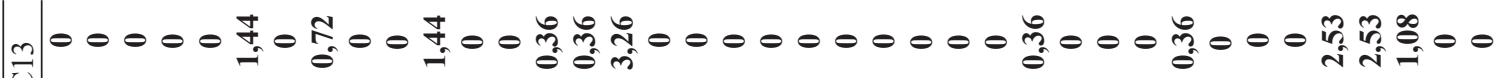

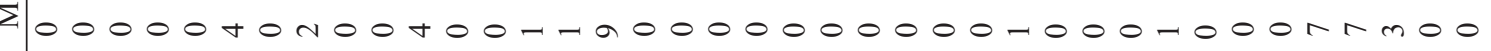

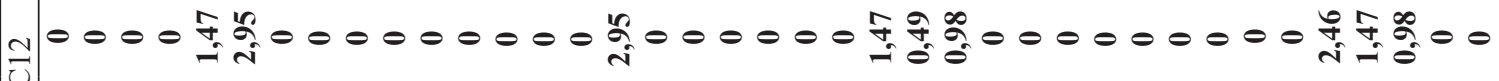

$\Sigma 0000 m 00000000000000000 m-n 000000000 \mathrm{~m} n 00$

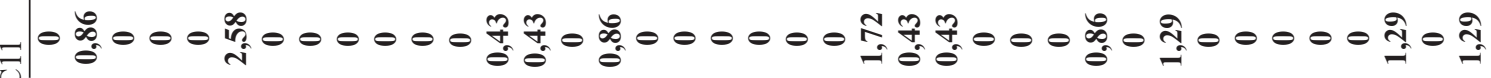

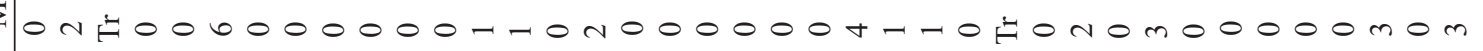

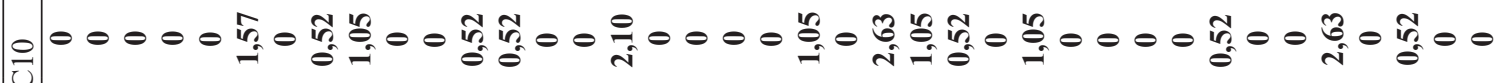

$\sum$

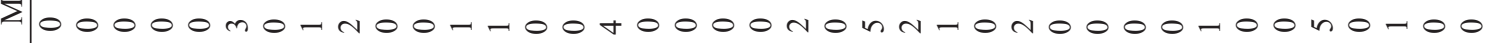

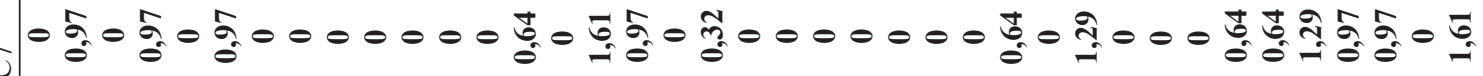

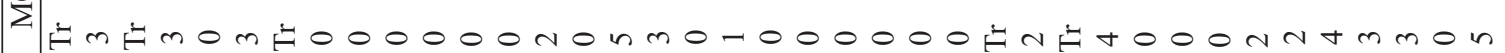

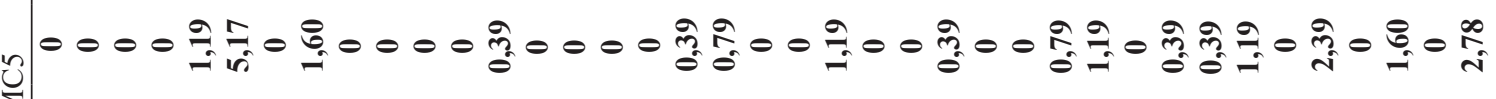

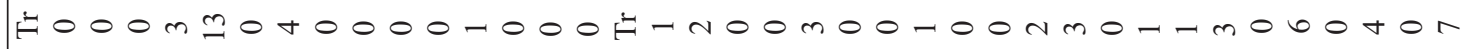

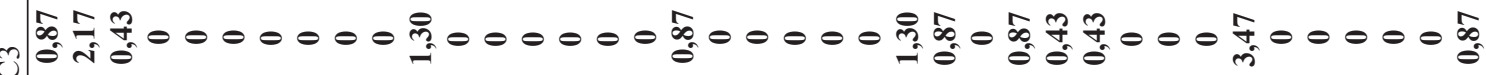

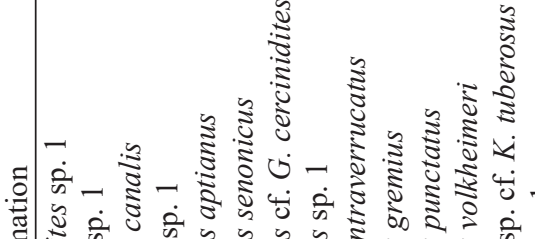

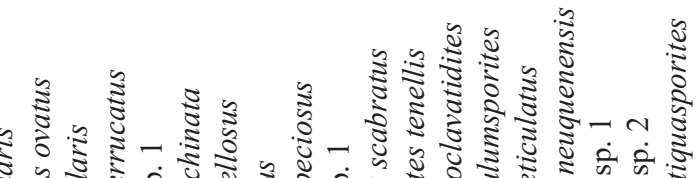

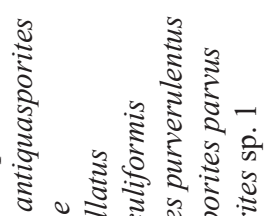

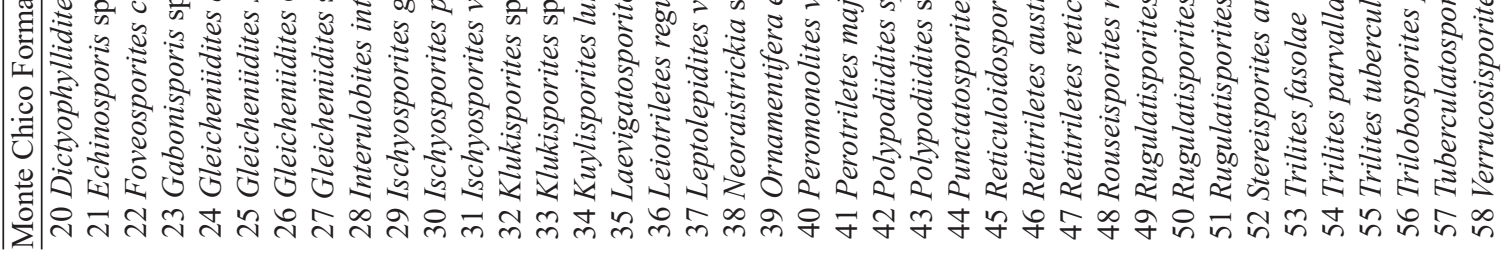




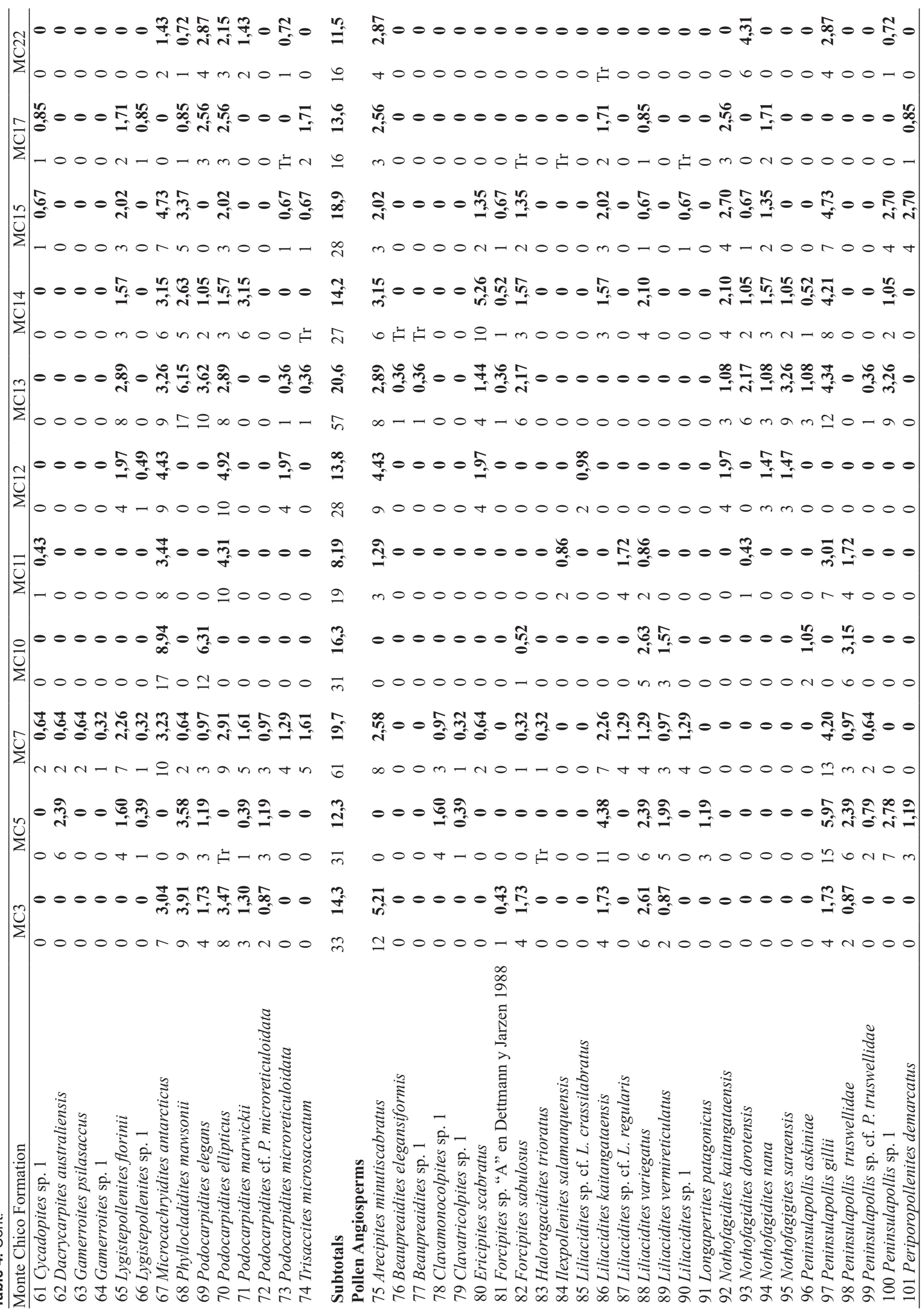




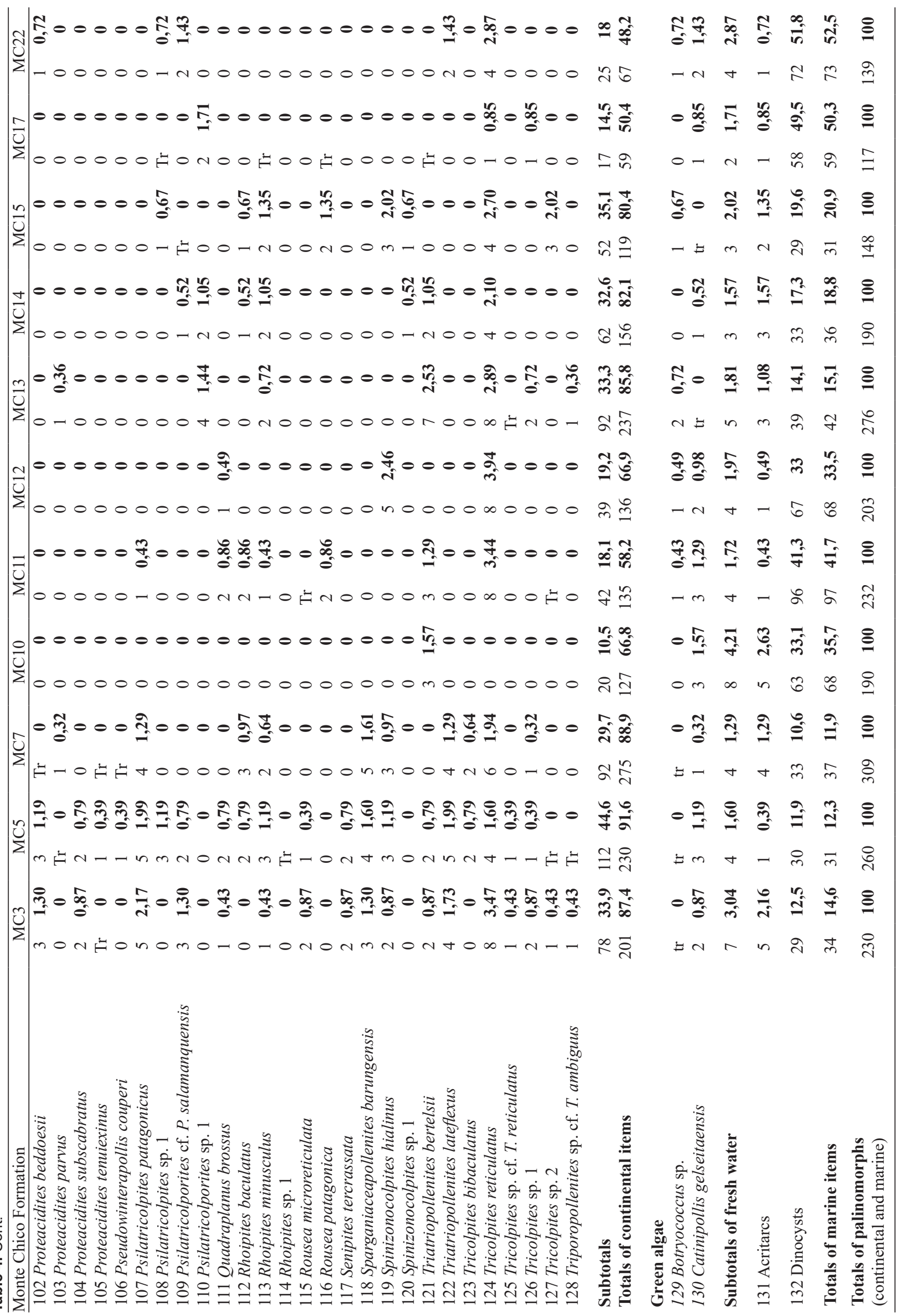




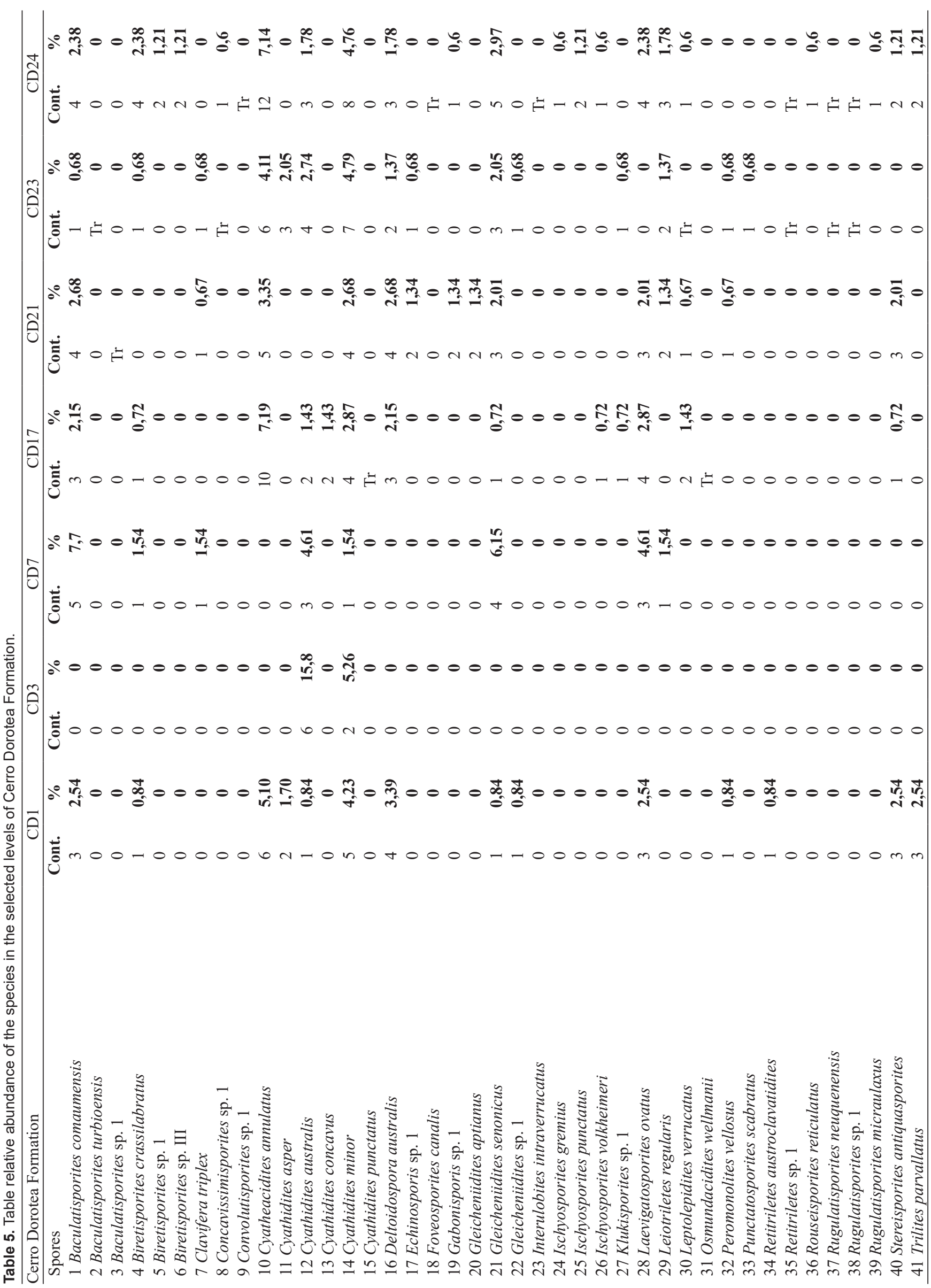




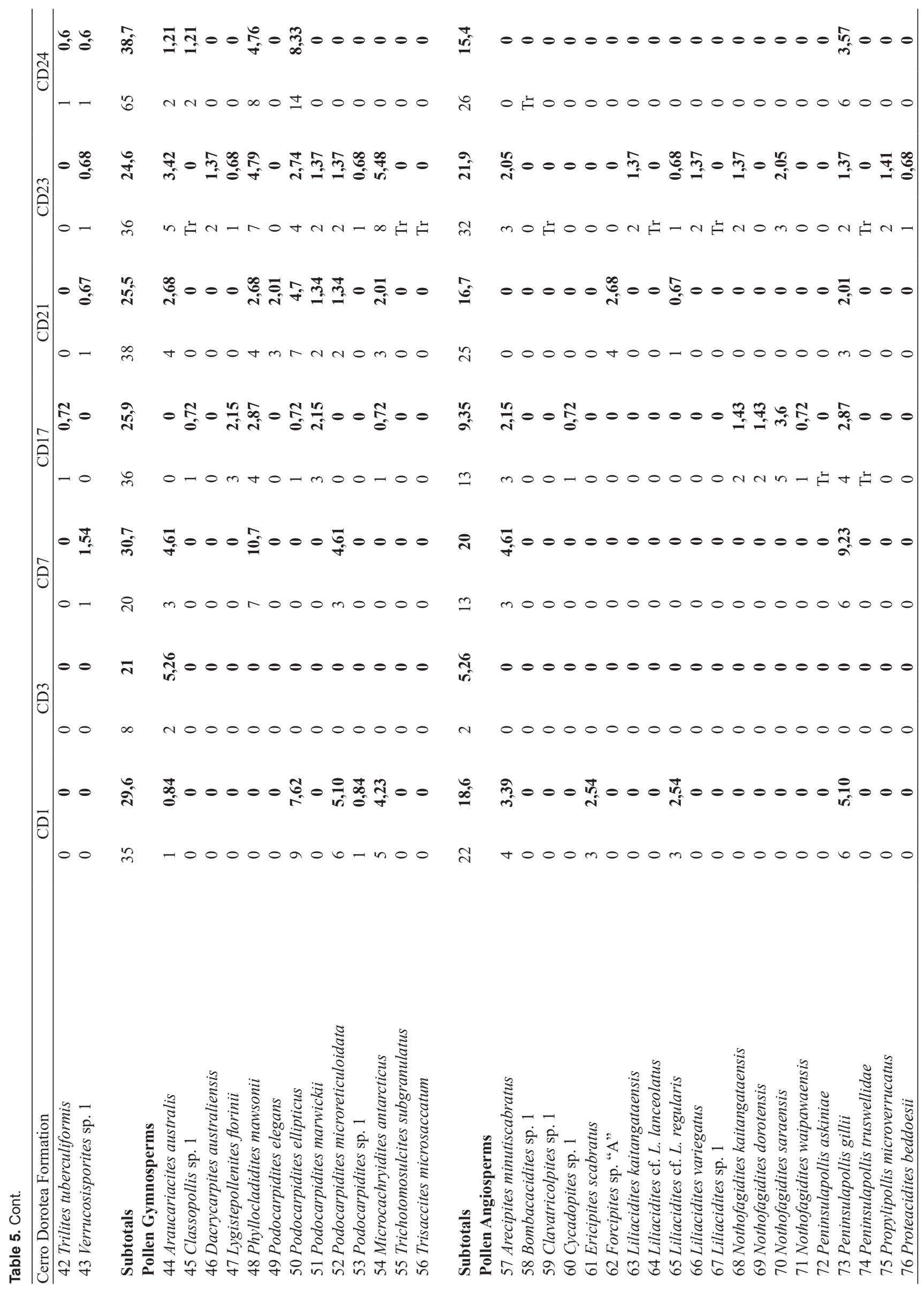




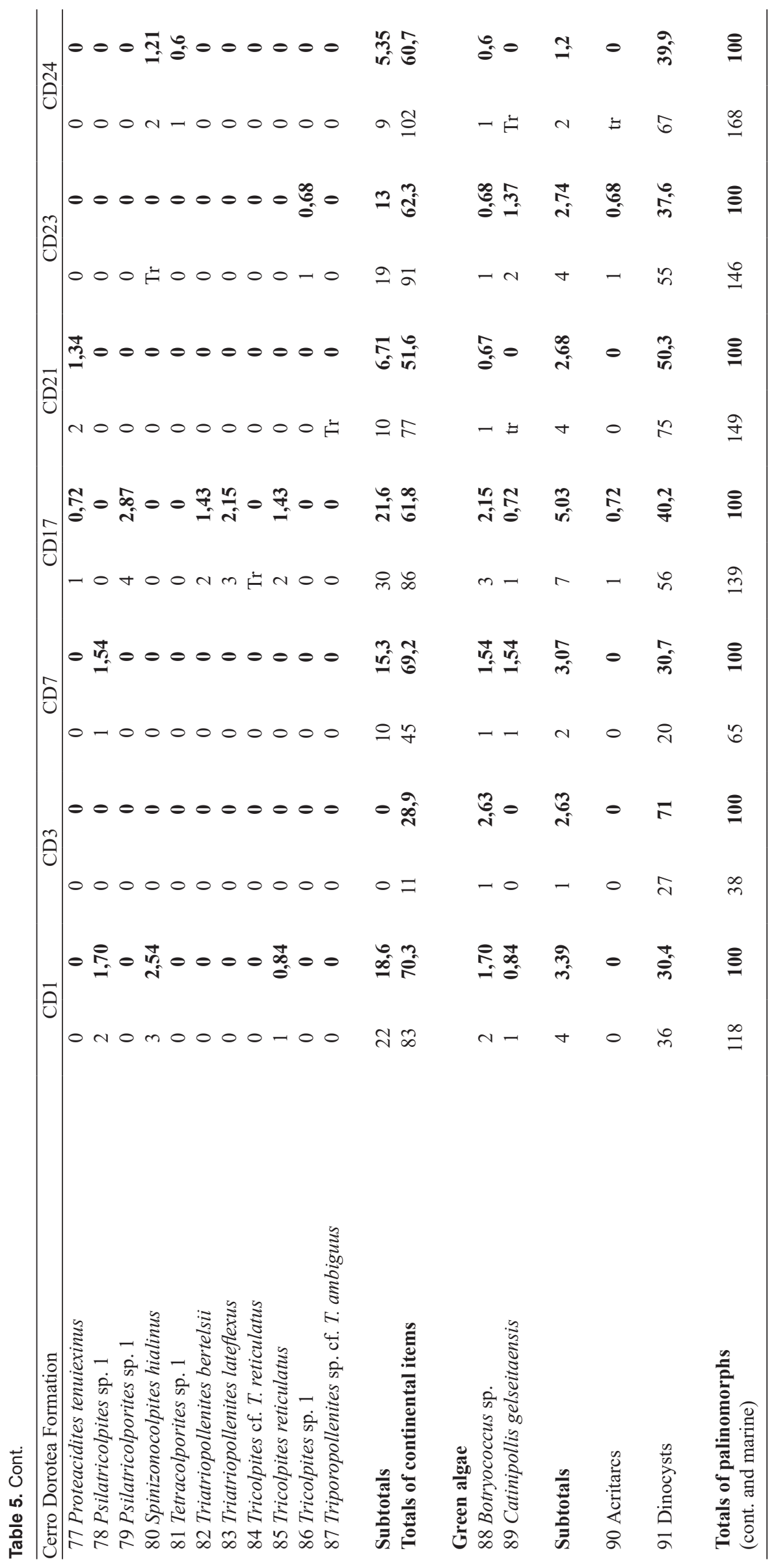




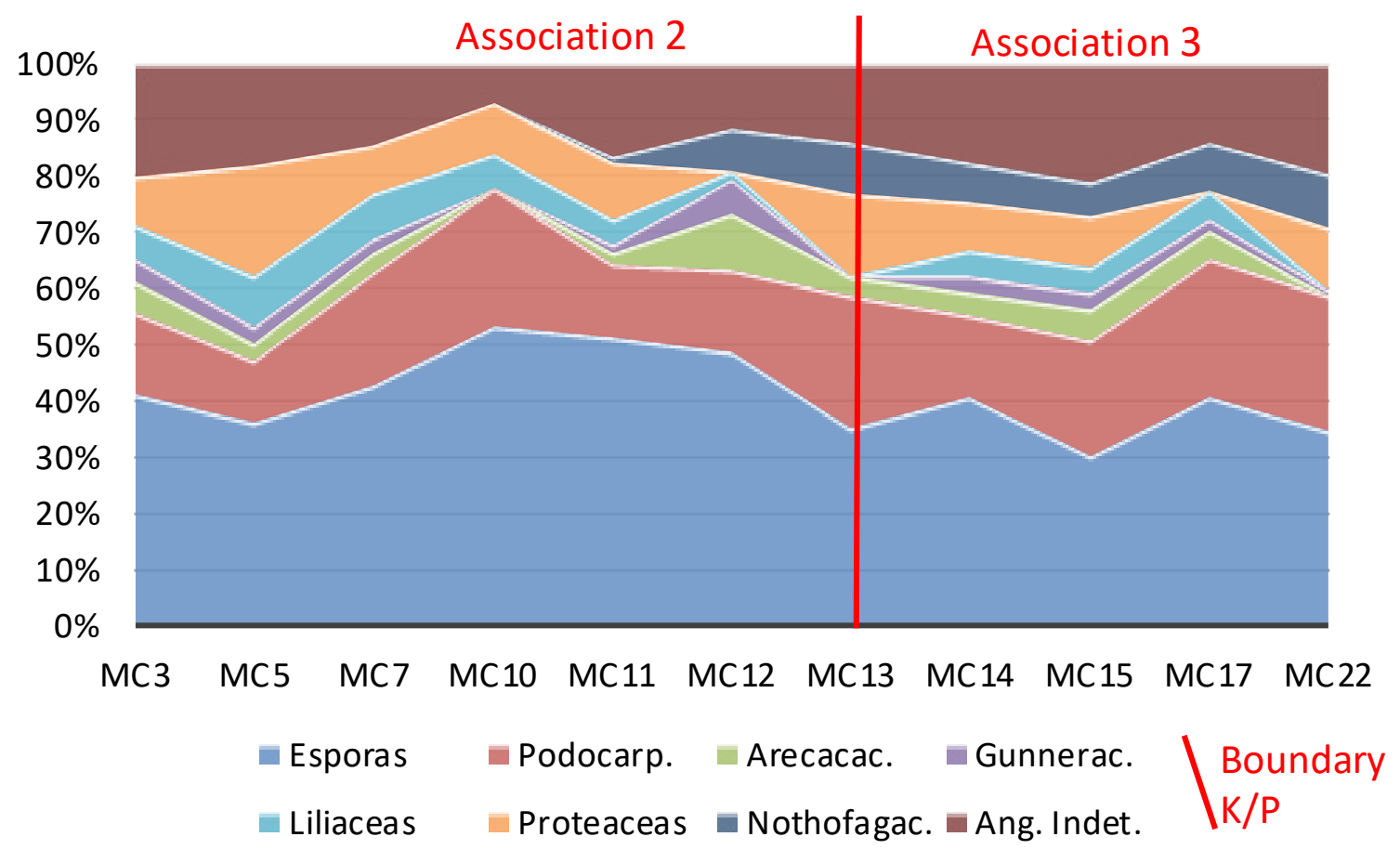

Figure 5. Graph showing the Cretaceous/Paleogene boundary suggested for Monte Chico Formation.

in the vegetation through the boundary, with a temporary loss of angiosperms and a sharp reduction in several groups of gymnosperms and spores (Pocock, 1962; Vajda et al., 2001; Vajda \& Raine, 2003; Barreda et al., 2004; Cúneo et al., 2008). According to the observations made in this paper it could be determined with a degree of certainty that the position of the Cretaceous-Paleogene boundary is located between Associations 2 and 3, as suggested in previous studies (Malumián \& Panza, 1996), in the Monte Chico Formation. Its location between these two associations is suggested mainly by the temporal ranges of some species of restricted distributions, especially Quadraplanus brossus and Nothofagidites dorotensis. Quadraplanus brossus is a characteristic species of the Tricolpites longus Zone defined for SE Australia (Helby et al., 1987) assigned to the upper Maastrichtian-basal Danian? and the Monte Chico Formation is virtually restricted to Association 2. On the other hand, Nothofagidites dorotensis, which has its first appearance in Association 3, has no record prior to the Danian.

At the moment, however, no significant changes in diversity and/or abundance of species between these two associations appear, as was documented for other basins in Argentina (Vajda \& Raine, 2003; Barreda et al., 2004; Cúneo et al., 2008). This result may be due on the one hand to (i) there having been no disturbance in the vegetation across the boundary in the southern sector of Patagonia, and/or (ii) that the level of detail of sampling is insufficient to document it.

\section{DISCUSSION AND CONCLUSIONS}

An analysis of the distribution of pollen and spore species in the units recognized four palynological associations with unique characteristics: Association 1, was recognized in the upper levels of the Cerro Cazador Formation and lacks the characteristic taxa of younger associations; Association 2, was recognized in the lower and middle levels of the Monte Chico Formation and lacks the characteristic elements of the lower (1) and upper (3, 4) associations; Association 3, was recognized in the upper section of Monte Chico Formation; and Association 4, was recognized in the Cerro Dorotea Formation (Figure 4).

Based on the known stratigraphic distribution of the species and observed affinities, it follows that Association 1 (upper levels of the Cerro Cazador Formation) has an inferred age of late Campanian-early Maastrichtian; Association 2 (lower and middle levels of the Monte Chico Formation) has an age in the region of the Maastrichtian, probably late Maastrichtian; Association 3 (higher levels of the Monte Chico Formation) has an inferred age limited to the proximity of the Maastrichtian-Danian; and Association 4 (Cerro Dorotea Formation) has a Danian age taking into account previous records (Archangelsky, 1973).

According to this analysis the position of the $\mathrm{K} / \mathrm{P}$ boundary would be located between Associations 2 and 3, within the Monte Chico Formation (Figure 5). However, no significant changes in the diversity and/or abundance of species between 
these two associations were seen, as was documented for other basins in Argentina. This result may be due on the one hand because (i) there has been no disturbance in the vegetation across the boundary in the southern sector of Patagonia and/ or (ii) the level of sampling detail is insufficient to document it. Further studies on these and other sections, with a greater level of detail, may provide new information to answer this question.

From the point of view of the depositional environment of the three units (Cerro Cazador, Monte Chico and Cerro Dorotea formations), they would have evolved in a marine environment with progressively more marginal conditions that would indicate a progressive shallowing of the basin.

From a paleoclimatic perspective, associations recovered from the Cerro Cazador Formation suggest the development of vegetation with a high participation of herbaceous elements, especially ferns and plants of a terrestrial habit such as Liliaceae and Gunneraceae. Among the dominant elements of palm trees and the Proteaceae, the Podocarpaceae may have evolved away from the depositional environment, judging by their low relative frequencies in relation to the high pollen productivity of the group. The prevailing paleoclimatic conditions would have been warm and wet.

The associations from the Monte Chico Formation suggest the development of plant communities dominated by Proteaceae and Arecaceae with a dense cover of ferns under a hot and wet climate. The abundance of ferns indicates the presence of flooded or wet soil.

Spore-pollen associations recovered from the Cerro Dorotea Formation show no significant differences to those from the underlying Monte Chico Formation. Both units are dominated by fern spores, followed by Arecaceae, Liliaceae and Proteaceae pollen. Besides, the frequence of Nothofagaceae and Podocarpaceae elements in the Cerro Dorotea Formation suggest a forest close to marginal marine paleoenvironment where they were deposited. The vegetation developed under temperate warm and humid conditions.

\section{ACKNOWLEDGEMENTS}

The author is deeply grateful to the CONICET and the National Agency for Promotion of Science and Technology for financial support (PICT 32320).

\section{REFERENCES}

Archangelsky, S. 1973. Palinología del Paleoceno de Chubut. 1. Descripciones sistemáticas. Ameghiniana, 10:339-399.

Archangelsky, S. \& de Seoane, L.V. 1994. Estudios palinológicos de la Formación Baqueró (Cretácico), Provincia de Santa Cruz, Argentina. VI. Ameghiniana, 31:41-53.

Archangelsky, S. \& Zamaloa, M.C. 1986. Nuevas descripciones palinológicas de las formaciones Salamanca y Bororó, Paleoceno de Chubut, República Argentina. Ameghiniana, 23:35-46.

Askin, R.A. 1988. The palynological record across the Cretaceous/ Tertiary transition on Seymour Island, Antarctica. Boulder, Geological Society of America, p. 155-162 (Memoir 169). doi:10.1130/MEM169-p155
Askin, R.A. 1990. Campanian to Paleocene spore and pollen assemblages of Seymour Island, Antarctica. Review of Palaeobotany and Palynology, 65:105-113. doi:10.1016/00346667(90)90061-M

Baldoni, A.M. 1992. Palynology of the Lower Lefipan Formation (Upper Cretaceous) of Barranca de Los Perros, Chubut Province, Argentina. Part 1. Cryptogam spores and gymnosperm pollen. Palynology, 16:117-136. doi:10.1080/01916122.1992.9989410

Baldoni, A.M. \& Askin, R.A. 1993. Palynology of the Lower Lefipan Formation (Upper Cretaceous) of Barranca de Los Perros, Chubut Province, Argentina. Part II. Angiosperm pollen and discussion. Palynology, 17:241-264. doi:10.1080/01916122. 1993.9989429

Baldoni, A.M. \& Barreda, V.D. 1986. Estudio palinológico de las Formaciones López de Bertodano y Sobral, Isla Vicecomodoro Marambio, Antártida. Boletim IG-USP, Série Científica, 17:89-98.

Barreda, V.D.; Palamarczuk, S. \& Chamberlain J.A. 2004. Vegetational disruption at the Cretaceous/Paleogene boundary in Neuquén, Argentina: evidence from spores and pollen. In: REUNIÓN ARGENTINA DE SEDIMENTOLOGÍA, 10, 2004. Resúmenes, San Luis, AAS, p. 185-186.

Borrello, A. 1956. Recursos Minerales de la República Argentina, III. Combustibles Sólidos Minerales. Revista del Instituto Nacional de Investigación de las Ciencias Naturales y Museo Argentino de Ciencias Naturales "Bernardino Rivadavia", Ciencias Geológicas, 5:1-665.

Brandmayr, J. 1945. Contribución al conocimiento geológico del extremo sud-sudoeste del Territorio de Santa Cruz (Región Cerro Cazador-Alto Río Turbio). Boletín Informaciones Petroleras, 256:415-437.

Carrillo-Berumen, R.; Quattrocchio, M.E. \& Helenes, J. 2013. Palinomorfos continentales del Paléogeno de las formaciones Chorrillo Chico y Agua Fresca, Punta Prat, Región de Magallanes, Chile. Andean Geology, 40:539-560.

Cookson, I.C. 1950. Fossil pollen grains of Proteaceous type from Tertiary deposits in Australia. Australian Journal of Biological Sciences, 3:166-177. doi:10.1071/BI9500166

Cúneo, N.R.; Johnson, K.; Scasso, R.; Barreda, V.; Brinkhuis, H.; Clyde, W.; Gandolfo, A. \& Wilf, P. 2008. The K-T boundary and the associated floral event in South America. The case for Patagonia. In: INTERNATIONAL PALYNOLOGICAL CONGRESS, 12, 2008. Abstracts, Bonn, p. 55.

Dettmann, M.E. \& Jarzen, D.M. 1988. Angiosperm pollen from uppermost Cretaceous strata of southeastern Australia and the Antarctic Peninsula. Hornsby, Association of Australasian Palaeontologists, p. 217-237 (Memoir 5).

Dettmann, M.E. \& Jarzen, D.M. 1990. The Antarctic/Australian rift valley: Late Cretaceous cradle of northeastern Australasian relicts? Review of Palaeobotany and Palynology, 65:131-144. doi:10.1016/0034-6667(90)90064-P

Dettmann, M.E. \& Thomson, M.R.A. 1987. Cretaceous palynomorphs from the James Ross Island area, Antarctica - a pilot study. Cambridge, British Antarctic Survey, p. 13-59 (Bulletin 77).

Diéguez, C. 2003. Flora y vegetación durante el Jurásico y el Cretácico. Córdoba, Real Jardín Botánico de Córdoba, p. 53-62 (Monografías 11).

Feruglio, E. 1938. El Cretácico Superior del Lago San Martín (Patagonia) y de las regiones adyacentes. Physis, 12:293-342.

Feruglio, E. 1949. Descripción Geológica de la Patagonia. Buenos Aires, Yacimientos Petrolíferos Fiscales, 1114 p.

Freile, C. 1972. Estudio palinológico de la Formación Cerro Dorotea (Maastrichtiano-Paleoceno) de la provincia de Santa Cruz. Revista Museo de La Plata, Sección Paleontológica, 6:39-63. 
Hauthal, R.H. 1898. Über patagonisches Tertiär etc. Zeitschrift der Deutschen Geologischen Gesellschaft, 50:436-440.

Helby, R.; Morgan, R. \& Partridge, A.D. 1987. A palynological zonation of the Australian Mesozoic. Hornsby, Association of Australasian Palaeontologists, 94 p. (Memoir 4).

Hoffstetter, R.; Fuenzalida, H. \& Cecioni, G. 1957. Lexique Stratigraphique Internacional. Amérique Latine, Fascicule 7, Chile-Chili, vol. 4. París, Centre Nacional de la Recherche Scientifique, $444 \mathrm{p}$.

Hünicken, M. 1955. Depósitos Neocretácicos y Terciarios del extremo SSW de Santa Cruz (Cuenca Carbonífera de Río Turbio). Revista del Instituto Nacional de Investigaciones de las Ciencias Naturales, Museo Argentino de Ciencias Naturales "Benardino Rivadavia", Ciencias Geológicas, 4:1-164.

Katz, H.R. 1963. Revision of Cretaceous Stratigraphy in Patagonian Cordillera of Ultima Esperanza, Magallanes Province, Chile. Boulder, American Association Petroleum Geologists, p. 506-524 (Bulletin 47).

Leanza, A.F. 1972. Andes patagónicos australes. In: A.F. Leanza (ed.) Geología Regional Argentina, Academia Nacional de Ciencias, p. 689-706.

Macphail, M. 1994. Impact of the K/T event on the southeast Australian flora and vegetation: mass extinction, niche disruption or nil? Palaeoaustral, 1:9-13.

Malumián, N. \& Panza, J. 1996. Hoja Geológica Yacimiento Río Turbio 5172 III. Buenos Aires, Servicio Geológico Minero Argentino.

Mautino, L.R. \& Anzotegui, L.M. 2002. Palinología de la Formación Chiquimil (Mioceno Superior), en Río Vallecito, Provincia de Catamarca, Argentina. Parte 2. Polen. Ameghiniana, 39:257-270.

McIntyre, D.J. 1968. Futher new pollen species from New Zealand Tertiary and uppermost Cretaceous deposits. New Zealand Journal of Botany, 6:177-204. doi:10.1080/002882 $5 X .1968 .10429057$

Menéndez, C. \& Caccavari, M.A. 1975. Las especies de Nothofagidites (polen fósil de Nothofagus) de sedimentos Terciarios y Cretácicos de Estancia La Sara, Norte de Tierra del Fuego, Argentina. Ameghiniana, 12:165-183.

Orth, C.J.; Gilmore, J.S.; Knight, J.D.; Pillmore, C.L.; Tschudy, R.H. \& Fassett, J.E. 1981. An iridium abundance anomaly at the palynological Cretaceous-Tertiary boundary in northern New Mexico. Science, 214:1341-1343. doi:10.1126/ science.214.4527.1341

Papú, O.H. 1988a. Estudio palinológico de la Formación Paso del Sapo (Cretácico Superior) en la localidad de "Los Fortines", Valle Medio del Río Chubut. Parte 1: Esporas Triletes, Laevigati y Apiculati. In: CONGRESO ARGENTINO DE PALEONTOLOGÍA Y BIOESTRATIGRAFÍA, 4, 1988. Actas, Mendoza, p. 63-73.

Papú, O.H. 1988b. Estudio palinológico de la Formación Paso del Sapo (Cretácico Superior) en la localidad de "Los Fortines", Valle Medio del Río Chubut. Parte II: Esporas Triletes, Murornati, Tricrassati y esporas Monoletes. In: CONGRESO ARGENTINO DE PALEONTOLOGÍA Y BIOESTRATIGRAFÍA, 4, 1988. Actas, Mendoza, p. 75-85.

Papú, O.H. 1989. Estudio palinológico de la Formación Paso del Sapo (Cretácico Superior), Valle Medio del río Chubut. Granos de polen, consideraciones estadísticas, paleoecológicas y paleoambientales. Ameghiniana, 25:193-202.

Papú, O.H. 1990. Contribución a la palinología estratigráfica de la Formación Malargüe, Cretácico Superior, sur de la Provincia de Mendoza, Argentina. Parte I: Especies terrestres y de aguas continentales. Ameghiniana, 27:289-303.
Papú, O.H. 2002. Nueva microflora de edad Maastrichtiana en la localidad de Calmu-Co, sur de Mendoza, Argentina. Ameghiniana, 39:415-426.

Papú, O.H. \& Sepúlveda, E.G. 1995. Datos palinológicos de la Formación Los Alamitos en la localidad de Montoniló, departamento 25 de mayo, Río Negro, Argentina. Sus relaciones con unidades colindantes coetáneas. In: CONGRESO ARGENTINO DE PALEONTOLOGÍA Y BIOESTRATIGRAFÍA, 6, 1995. Actas, Trelew, p. 195-200.

Pascual, R. \& Jaureguizar, E.O. 1990. Evolving climates and mammal faunas in Cenozoic South America. Journal of Human Evolution, 19:23-60. doi:10.1016/0047-2484(90)90011-Y

Pascual, R.; Vucetich, M.G.; Scillato-Yané, G.J. \& Bond, M. 1985. Main pathways of mammalian diversification in South America. In: F.G. Stehli \& S.D. Webb (eds.) The Great American Biotic Interchange, New York, Springer-Verlag, p. 219-247 (Topics in Geobiology 4). doi:10.1007/978-1-4684-9181-4_8

Pocock, S.A.J. 1962. Microfloral analysis and age determination of strata at the Jurassic-Cretaceous boundary in the western Canada plains. Palaeontographica Abteilung B, 111:1-95.

Povilauskas, L.; Barreda, V. \& Marenssi, S. 2008. Polen y esporas de la Formación La Irene (Maastrichtiano), sudoeste de la provincia de Santa Cruz, Argentina: primeros resultados. Geobios, 41:819-831. doi:10.1016/j.geobios.2008.07.002

Povilauskas, L. \& Guler, M.V. 2008. Palinología de la Formación Cerro Cazador (Cretácico Superior), SO de la Provincia de Santa Cruz, Argentina. In: SIMPÓSIO BRASILEIRO DE PALEOBOTÂNICA E PALINOLOGIA, 12, 2008. Boletim de Resumos, Florianópolis, p. 166.

Povilauskas, L.; Palamarczuk, S.; Barreda, V.; Bellosi, E.; Novas, F.; Ambrosio, A. \& Ottone, G. 2006. Edad y paleoambiente de depósitos del Cretácico tardío del SO de la Provincia de Santa Cruz: evidencias palinológicas. In: SIMPOSIO ARGENTINO DE PALEOBOTÁNICA Y PALINOLOGÍA, 13, 2006. Resúmenes, Bahía Blanca, p. 51.

Punt, W.; Hoen, P.P.; Blackmore, S.; Nilsson, S. \& Le Thomas, A. 2007. Glossary of pollen and spore terminology. Review of Palaeobotany and Palynology, 143:1-81. doi:10.1016/j. revpalbo.2006.06.008

Quattrocchio, M.; Volkheimer, W. \& Del Papa, C. 1997. Palynology and paleoenvironment of the "Faja Gris"; Mealla Formation (Salta Group) at Garabatal Creek (NW Argentina). Palynology, 21:231-247. doi:10.1080/01916122.1997.9989498

Riccardi, A.C. \& Rolleri, E.O. 1980. Cordillera patagónica austral. In: SIMPOSIO GEOLÓGICO REGIONAL ARGENTINO, 2, 1980. Actas, Córdoba, ANC, p. 1163-1306.

Romero, E.J. 1973. Polen fósil de Nothofagus (Nothofagidites) del Cretácico y Paleoceno de Patagonia. Revista Museo La Plata, Sección Paleontológica, 7:291-303.

Romero, E.J. \& Zamaloa, M.C. 1997. A key for the identification of the species and an update of the record of Nothofagidites from South America. Ameghiniana, 34:207-214.

Ruiz, L. \& Quattrocchio, M.E. 1997. Estudio palinológico de la formación Pedro Luro (¿Maastrichtiano-Paleoceno) en la Cuenca del Colorado, República Argentina. Parte 1: esporas triletes, laevigati, murornati, tricrassati, cingulati y zonati. Revista Española de Micropaleontología, 29:13-30.

Stover, L.E. \& Partridge, A.D. 1973. Tertiary and Late Cretaceous spores and pollen from the Gippsland Basin, southeastern Australia. Proceedings of the Royal Society of Victoria, 85:237-286.

Truswell, E.M. 1983. Recycled Cretaceous and Tertiary pollen and spores in Antarctic marine sediments: a catalogue. Palaeontographica Abteilung B, 186:121-174. 
Vajda, V. \& Raine, J.I. 2003. Pollen and spores in marine Cretaceous/ Tertiary boundary sediments at mid-Waipara River, North Canterbury, New Zealand. New Zealand Journal of Geology and Geophysics, 46:255-273. doi:10.1080/00288306.2003.9515008

Vajda, V.; Raine J.I. \& Hollis, C.J. 2001. Indication of Global deforestation at the Cretaceous-Tertiary boundary by New Zealand fern spike. Science, 294:1700-1702. doi:10.1126/ science. 1064706

Volkheimer, W. \& Melendi, D. 1976. Palinomorfos como fósiles guía ( $3^{\circ}$ parte). Técnicas de Laboratorio palinológico. Revista Minera, Geología y Mineralogía, 34:119-130.
Wilckens, O. 1907. Eulaterungen zu R. Hauthals Geologischer Skizze des Gebietes Zwischen dem Lago Argentino und dem Seno de la Última Esperanza (Südpatagonien). Berichten der Naturforschenden Gesellschaft zu Freiburg, 15:75-97.

Received in July, 2016; accepted in August, 2017. 
Appendix 1. List of species found.

Assemblage 1 (Cerro Cazador Formation)

Baculatisporites cf. B. comaumensis (Cookson) Potonié, 1956

Biretisporites cf. B. potoniaei Delcourt \& Sprumont, 1955

Ischyosporites sp. 1

Podocarpidites sp. 2

Trilites cf. T. fasolae Archangelsky, 1972

Triporopollenites sp. 1

Verrucosisporites sp. 2

Assemblage 2 (basal levels and middle of Monte Chico Formation)

Baculatisporites turbioensis Archangelsky, 1972

Beaupreaidites elegansiformis Cookson, 1950

Biretisporites crassilabratus Archangelsky, 1972

Camarozonosporites ohaiensis (Couper, 1953) Dettmann \& Playford, 1968

Ceratosporites equalis Cookson \& Dettmann, 1958

Classopollis sp. 1

Forcipites sabulosus (Dettmann \& Playford) Dettmann \& Jarzen, 1988

Haloragacidites trioratus Couper, 1953

Ilexpollenites salamanquensis Archangelsky, 1986

Liliacidites vermireticulatus Archangelsky y Zamaloa, 1986

Longapertites patagonicus Archangelsky, 1973

Nothofagidites kaitangataensis (Te Punga) Romero, 1973

Ornamentifera echinata (Bolkhovitina) Bolkhovitina, 1966

Peninsulapollis truswellidae Dettmann \& Jarzen, 1988

Periporopollenites demarcatus Stover, 1973

Peromonolites vellosus Partridge, 1973

Proteacidites beddoesii Stover, 1973

Proteacidites subscabratus Couper, 1960

Proteacidites tenuiexinus Stover in Stover \& Partridge, 1973

Psilatricolpites patagonicus Freile, 1972

Psilatricolporites cf. P. salamanquensis Archangelsky \& Zamaloa, 1986

Quadraplanus brossus (Stover) Stover \& Partridge, 1973

Rhoipites baculatus Archangelsky, 1973

Rhoipites minusculus Archangelsky, 1983

Rousea microreticulata Archangelsky, 1986

Rousea patagonica Archangelsky, 1973

Senipites tercrassata Archangelsky, 1973

Sparganiaceapollenites barungensis Harris, 1972

Spinizonocolpites hialinus Zamaloa \& Archangelsky, 1986

Triatriopollenites bertelsii Archangelsky, 1973

Trilites tuberculiformis Cookson, 1947

Tricolpites bibaculatus Archangelsky \& Zamaloa, 1986

Triporopollenites cf. T. ambiguus (Stover) Stover \& Partridge, 1973

Tuberculatosporites parvus Archangelsky, 1972

Assemblage 3 (upper levels of Monte Chico Formation)

Beaupreaidites sp. 1

Ericipites scabratus Harris, 1965

Gamerroites psilasaccus (Archangelsky \& Romero, 1974) Archangelsky, 1988

Liliacidites sp. 1

Nothofagidites dorotensis Romero, 1973

Nothofagidites nana Romero, 1977

Peninsulapollis askiniae Dettmann \& Jarzen, 1988

Pseudowinterapollis couperi Krutzsch, 1970 emend. Mildenhall, 1979 
Assemblage 4 (Cerro Dorotea Formation)

Bombacacidites sp. 1

Forcipites stipulatus (Stover \& Evans) Dettmann \& Jarzen 1988

Nothofagidites waipawaensis (Couper 1960) Fasola 1969,

Propylipollis microverrucatus Truswell \& Owen, 1988

Tetracolporites sp. 1 